BIS WORKING PAPERS

No. 71 - June 1999

\title{
THE TERM STRUCTURE OF
} ANNOUNCEMENT EFFECTS

by

Michael J Fleming and Eli M Remolona

BANK FOR INTERNATIONAL SETTLEMENTS

Monetary and Economic Department

Basel, Switzerland 
BIS Working Papers are written by members of the Monetary and Economic Department of the Bank for International Settlements, and from time to time by other economists, and are published by the Bank. The papers are on subjects of topical interest and are technical in character. The views expressed in them are those of their authors and not necessarily the views of the BIS.

Copies of publications are available from:

Bank for International Settlements

Information, Press \& Library Services

$\mathrm{CH}-4002$ Basel, Switzerland

Fax: +41 61 / 2809100 and +4161/2808100

This publication is available on the BIS website (www.bis.org).

(C) Bank for International Settlements 1999.

All rights reserved. Brief excerpts may be reproduced or translated provided the source is stated. 


\title{
BIS WORKING PAPERS
}

No. 71 - June 1999

\section{THE TERM STRUCTURE OF} ANNOUNCEMENT EFFECTS

by

Michael J Fleming and Eli M Remolona*

\begin{abstract}
We analyse high-frequency responses of the US yield curve to macroeconomic announcements, exploiting the high signal-to-noise ratios of these events. Surprises in the announcements evoke relatively weak reactions from the short maturities and the strong ones from the intermediate maturities. Thus the term structure of announcement effects is hump-shaped. We fit an affine-yield model to the yield changes, using the announcement surprises as instruments for the Generalised Method of Moments (GMM). The model estimates imply that the announcements impose larger shocks on an expected future target interest rate than on the current short-term interest rate and that different types of announcements generate different expectations about this target rate, how rapidly it will be approached, and how long it will be maintained.
\end{abstract}

Key words: Announcements; Term structure: Expectations.

JEL classification: E43; E44; G14.

* Michael Fleming is with the Federal Reserve Bank of New York and Eli Remolona with the Bank for International Settlements. They received helpful comments from David Backus, John Campbell, Young Ho Eom, Jordi Gali, Kenneth Garbade, Ravi Jagannathan, Charles Jones, Henri Pages, Tony Rodrigues and seminar participants at the Eastern Economic Association Annual Meeting (1998), the FMA Annual Meeting (1998), the Bank of England, the Bank for International Settlements, the Bank of Japan and the Federal Reserve Bank of New York. Research assistance by Natalia Millan is gratefully acknowledged. Stephan Arthur oversaw the preparation of the paper for this working paper series. The views expressed are the authors' and not necessarily those of the Bank for International Settlements, the Federal Reserve Bank of New York or the Federal Reserve System. 


\section{Contents}

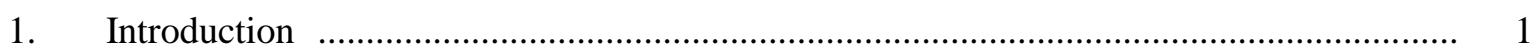

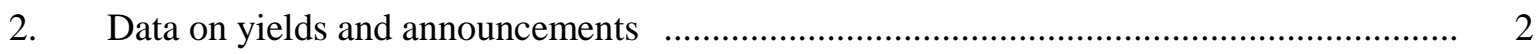

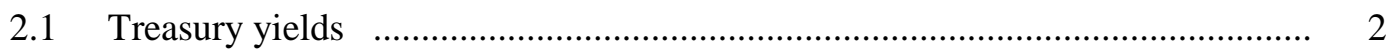

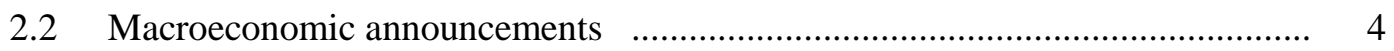

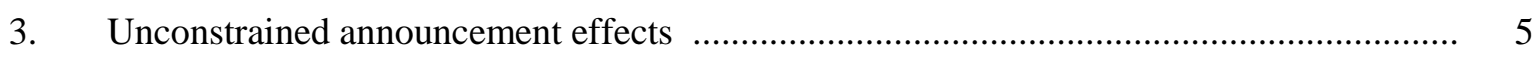

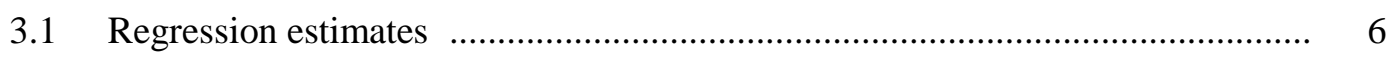

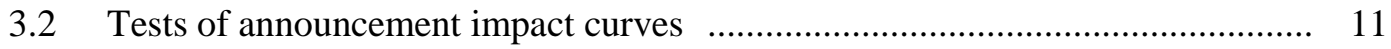

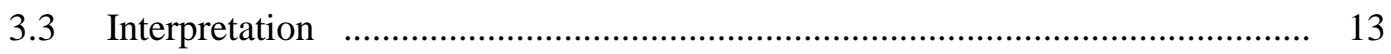

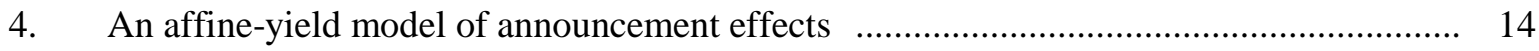

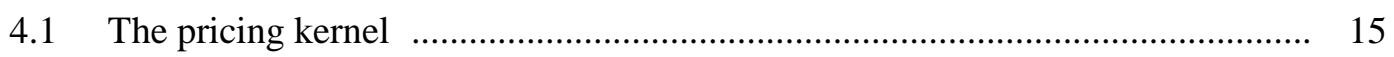

4.2 Expectations processes within a month f..................................................... 15

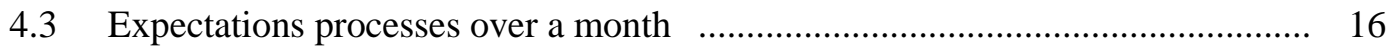

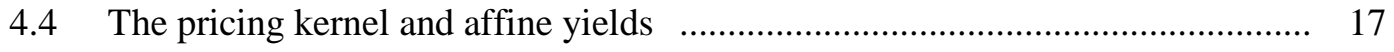

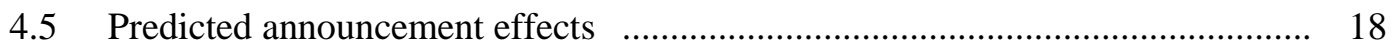

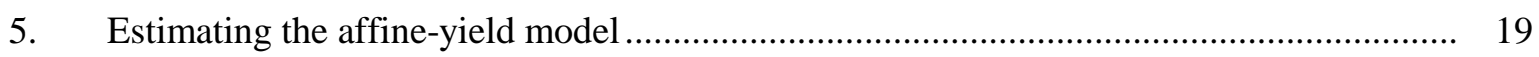

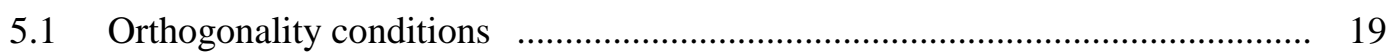

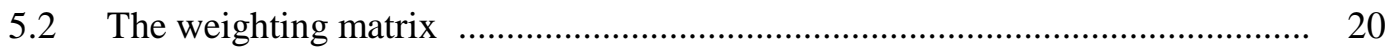

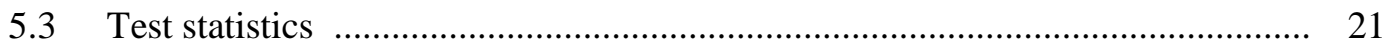

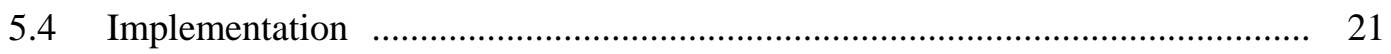

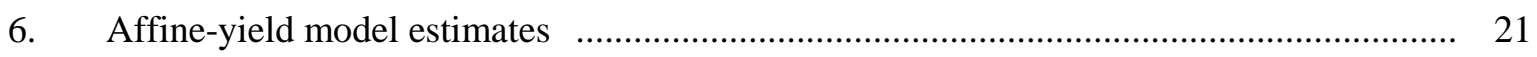

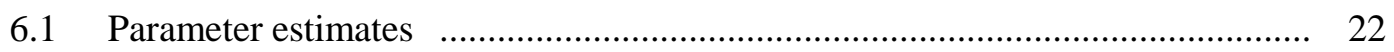

6.2 Implied announcement impact curves f.................................................. 23

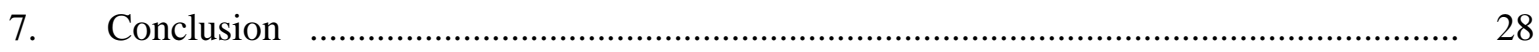

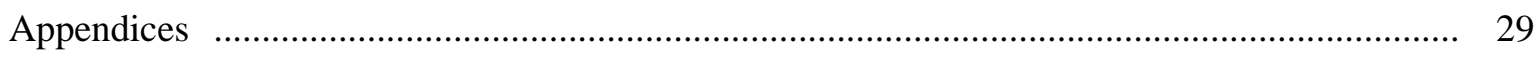

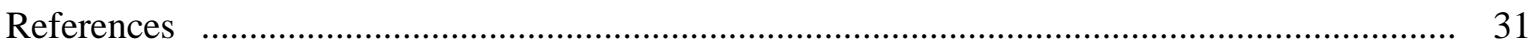




\section{Introduction}

Finance theory tells us that the term structure encapsulates the market's views of the future behaviour of short-term interest rates. The arrival of information leads to a revision of expectations and thus moves the yield curve. Theoretical work with affine-yield models since Vasicek (1977) and Cox, Ingersoll and Ross (1985) exploits arbitrage conditions to establish precise links between such yield movements and shocks to expectational factors. In the empirical literature, Longstaff and Schwartz (1992), Chen and Scott (1993) and Duffie and Singleton (1997), among others, extract estimates of parameters describing the underlying factor process. The estimates are typically based on time series data of weekly or monthly interest rates without explicit regard for news arrival. Since yield changes over such frequencies necessarily reflect an amalgam of information, it is difficult to interpret the estimated parameters in terms of fundamentals.

A separate and extensive literature has established the significance to the bond market of various scheduled macroeconomic announcements (Fleming and Remolona (1997) survey 21 of these studies). While early studies (e.g. Grossman (1981) and Urich and Wachtel (1981)) focus on money supply announcements, more recent work (e.g. Hardouvelis (1988) and Edison (1996)) documents the importance of employment, producer price index (PPI), consumer price index (CPI), and other announcements. Jones, Lamont, and Lumsdaine (1998) find that such announcements are sufficiently important to the market for Treasury securities to command discernible risk premia in their anticipation. While most announcement studies analyse daily data, high-frequency studies of Ederington and Lee (1993) and Fleming and Remolona (1998) show that most of the price response to scheduled macroeconomic announcements is completed within one or two minutes. This rapid response to important news leads to Fleming and Remolona's (1997) finding that the largest fiveminute price changes in the bond market occur immediately after the release of scheduled macroeconomic announcements.

In spite of the announcements' importance, few studies examine their impact on the yield curve as a whole. Most studies look at a single bill yield, a few yields from one part of the maturity spectrum, or a short-term yield and a long-term yield. Even when they do consider more than a single yield, there is typically no attempt to relate announcement effects across maturities. Exceptions are Roley and Walsh (1985) and Cook and Hahn (1987), which measure the effects of money supply announcements on a full range of maturities with daily data from October 1979 to October 1982 and find downward sloping announcement impact curves. More recently, Balduzzi, Elton, and Green (1998) examine announcement effects for four Treasury securities, but they focus on prices, trading volume and bidask spreads, rather than the pattern of effects across the yield curve. The literature thus still lacks an analysis of announcement effects for the entire yield curve for announcements that are important in the present market. 
In this paper, we document and interpret the impact of macroeconomic announcements on the entire yield curve. High-frequency data from the interdealer broker market allow us to exploit the high signal-to-noise ratio of the yield curve's response in narrow five-minute intervals around the announcements. We first use least squares regressions to estimate the unconstrained impact of surprises of 10 announcements on the yields of eight US Treasury securities, ranging from the threemonth bill to the 30-year bond. The patterns we find are striking. The announcement effects are relatively weak for the short maturities and strong for the intermediate maturities of one to five years. When graphed by bond maturity, these effects form hump-shaped curves. Moreover, these humpshaped curves differ somewhat by announcement type, demonstrating that information is heterogeneous with respect to its impact on the term structure.

The hump-shaped announcement impact curves imply certain expectation processes for interest rates. To extract these processes, we fit an affine-yield model to the announcement effects. The particular model is one driven by an interaction between factors, with one factor reverting over time to a stochastic mean. We estimate the model by the generalised method of moments (GMM), using the announcement surprises themselves as instruments. Our estimates imply that the announcements elicit relatively large shocks to an expected future target interest rate and that different types of announcements generate different expectations about this target rate, how rapidly it will be approached, and how long it will be maintained.

In Section 2, we describe the data on Treasury yields and announcements. In Section 3, we analyse announcement effects through regressions that are not restricted by a term structure model. In Section 4, we specify a multi-factor affine-yield model that treats announcement surprises as sources of factor shocks. In Section 5, we discuss GMM estimation of the model. In Section 6, we present the model results. In Section 7, we conclude.

\section{Data on yields and announcements}

\subsection{Treasury yields}

Our US Treasury data cover four years and three months, from 1 July 1991 to 29 September 1995. The source of the data is GovPX, Inc., a joint venture set up in 1991 by the primary dealers and interdealer brokers to improve public access to Treasury prices. GovPX consolidates data from five of the six interdealer brokers, accounting for roughly two-thirds of the market, and transmits the data to subscribers real-time through on-line vendors. The posted data include the best bid and offer quotes and the price and size of each trade. 
We focus our analysis on the eight on-the-run Treasury securities: the three-month bill, six-month bill, one-year bill, two-year note, three-year note, five-year note, 10 -year note, and 30-year bond. ${ }^{1}$ Table 1 reports the mean daily yield, the standard deviation of daily yield changes, and the mean Macaulay duration for each security over our sample period. Mean yields range from $4.2 \%$ for the three-month bill to $7.3 \%$ for the 30-year bond, characteristic of an upward sloping yield curve. The standard deviations of yield changes indicate a volatility curve that is hump-shaped, with the three-year note showing the highest volatility. Mean durations are equal to the average time to maturity for the bills, and less than time to maturity for the coupon-bearing securities, with the 30-year bond having a mean duration of just 12.4 years.

Table 1

Treasury security descriptive statistics

\begin{tabular}{lccc}
\hline Security & Mean yield $(\boldsymbol{\%})$ & $\begin{array}{c}\text { Standard deviation of } \\
\text { yield changes }(\mathbf{b p})\end{array}$ & $\begin{array}{c}\text { Mean Macaulay } \\
\text { duration (years) }\end{array}$ \\
\hline 3-month bill & 4.18 & 4.27 & 0.25 \\
6-month bill & 4.41 & 4.74 & 0.50 \\
1-year bill & 4.66 & 5.74 & 0.97 \\
2-year note & 5.29 & 6.55 & 1.89 \\
3-year note & 5.62 & 6.76 & 2.69 \\
5-year note & 6.22 & 6.68 & 4.33 \\
10-year note & 6.79 & 6.03 & 7.23 \\
30-year bond & 7.28 & 4.98 & 12.38 \\
\hline
\end{tabular}

Notes: Statistics are calculated using end of day yields of eight on the run Treasury securities. The sample period is 1 July 1991 to 29 September 1995.

In calculating the yield curve's response to macroeconomic announcements, we exploit the highfrequency nature of the GovPX data. For each day and each on-the-run security, we calculate the change in yield from the last transaction before 8.30 a.m. to the first transaction after 8.35 a.m. ${ }^{2}$ Use of this narrow time window allows us to capture the response of the yield curve to 8.30 a.m. macroeconomic announcements with minimal contamination from confounding economic events and follows from the finding that the bulk of the Treasury market price response to major macroeconomic announcements is completed within one or two minutes (Ederington and Lee (1993) and Fleming and

1 On-the-run securities are the most recently issued securities of a given maturity and account for the majority of interdealer trading volume (Fleming (1997)). The seven-year note, last auctioned on 13 April 1993, was on-the-run for only part of our sample period and is thus excluded from our analysis.

2 Treasury securities trade with differing frequency across days and securities resulting in varying interval lengths between the last trade before $8.30 \mathrm{a}$ am. and the first trade after $8.35 \mathrm{a} . \mathrm{m}$. For the on-the-run five-year note, for example, there is a trade between 8.25 and 8.30 a.m. on $98.0 \%$ of the sample days and a trade between 8.35 and 8.40 a.m. on $98.5 \%$ of the days. The corresponding figures for the three-month bill are just $26.3 \%$ and $39.0 \%$, respectively. The last trade before 8.30 a.m. is often the preceding afternoon for Treasury bills due to the lack of bill activity in the overnight and early morning hours. 
Remolona (1998)). After excluding 43 non-trading days and six days with missing or incomplete data, we retain 1,061 days for which we calculate these five-minute yield changes. ${ }^{3}$

\subsection{Macroeconomic announcements}

We collected data on 10 macroeconomic announcements: (1) CPI, (2) durable goods orders, (3) gross domestic product (GDP), (4) housing starts, (5) jobless rate, (6) leading indicators, (7) nonfarm payrolls, (8) PPI, (9) retail sales and (10) trade balance. ${ }^{4}$ These announcements are released once a month on scheduled dates at 8.30 a.m., and are regularly profiled in "The Week Ahead" section of Business Week, among other places. ${ }^{5}$ The group contains the number found to have the largest impact on the market in recent years, nonfarm payrolls, which is released with the jobless rate as part of the monthly employment report. The group also covers wide terrain in its content, with information ranging from labour market conditions to inflation pressures to changes in aggregate demand.

An important aspect of these macroeconomic announcements is that they are released widely and completely at precisely 8.30 a.m. The government statistical agencies impose "lock-up" conditions to ensure that the information is released at only the scheduled time. ${ }^{6}$ Market participants know the release times in advance, anticipate the releases and receive the reports via electronic news services at the same time. Furthermore, the nature of the information released is transparent enough for market participants' expectations about interest rates to be immediately and sharply revised. These features of the announcements make high-frequency data particularly helpful for our analysis and allow us to examine market effects over a narrow five-minute window.

Market expectations for the announcements are obtained from Barron's and the Wall Street Journal. Every week, Barron's and the Wall Street Journal publish consensus forecasts provided by Technical Data for the coming week's announcements. ${ }^{7}$ Technical Data produces the forecasts from a survey of 25 economists conducted the previous Friday. We refer to Business Week (which relies on MMS International) for discrepancies between, or forecasts missing from, the first two sources. Actual

Our sample includes three days (all Good Fridays) on which macroeconomic announcements were released but on which there was limited to no trading activity. For some of these days and securities, the last yield before 8.30 a.m. comes from the previous trading day and the first yield after 8.35 a.m. comes from the following trading day.

4 GDP data are for gross national product until that report was replaced in December 1991; trade balance data for merchandise trade until that report was replaced in March 1994.

5 Personal income is not included in our sample as it has only been reported at 8.30 a.m. since December 1993. Although GDP is a quarterly measure, advance, preliminary and final estimates are released in successive months.

6 These lockup conditions are detailed in Fleming and Remolona (1998). In spite of these precautions, the employment report was inadvertently released early via the Bureau of Labor Statistics' website in November 1998, and the PPI report was released early in January 1999. We are not aware of any similar episodes during our sample period.

7 In the early part of our sample period, the Wall Street Journal reported data from MMS International and Barron's reported data from Thomson Financial Networks. 
announcement data are retrieved from these three sources and supplemented by data from Bloomberg when necessary. Announcement surprises are then calculated by subtracting the forecasts from the actual numbers released. In our 51-month sample period we have 51 surprises for nine of the 10 announcements and 50 announcements for the other. ${ }^{8}$ Descriptive statistics for these surprises are reported in Table 2.

Table 2

Announcement surprise descriptive statistics

\begin{tabular}{lrcccc}
\hline Announcement & Mean & $\begin{array}{c}\text { Standard } \\
\text { deviation }\end{array}$ & Minimum & Maximum & $\begin{array}{c}\text { Mean } \\
\text { absolute }\end{array}$ \\
\hline Consumer price index (\%) & -0.022 & 0.122 & -0.3 & 0.3 & 0.092 \\
Durable goods orders (\%) & 0.145 & 2.677 & -4.5 & 9.5 & 2.024 \\
Gross domestic product (\%) (1, $^{1,2}$ & 0.046 & 0.457 & -1.0 & 1.2 & 0.362 \\
Housing starts (million houses) & 0.006 & 0.072 & -0.175 & 0.124 & 0.058 \\
Jobless rate (\%) & -0.055 & 0.165 & -0.4 & 0.4 & 0.133 \\
Leading indicators (\%) & 0.004 & 0.164 & -0.4 & 0.5 & 0.120 \\
Nonfarm payrolls (thousand jobs) & -15.353 & 112.896 & -276 & 250 & 88.255 \\
Producer price index (\%) & -0.084 & 0.240 & -0.8 & 0.6 & 0.186 \\
Retail sales (\%) & -0.061 & 0.459 & -1.1 & 1.0 & 0.367 \\
Trade balance (\$ billion) ${ }^{3}$ & -0.408 & 1.452 & -4.0 & 3.1 & 1.105 \\
\hline
\end{tabular}

Notes: Announcement surprises are calculated as the differences between the actual numbers announced and the consensus forecasts from surveys of economists. The sample period is 1 July 1991 to 29 September 1995.

${ }^{1}$ Gross national product until December 1991. ${ }^{2}$ Annualised. ${ }^{3}$ Merchandise trade balance until March 1994.

\section{Unconstrained announcement effects}

We first analyse the impact of announcement surprises on Treasury yields without imposing the structure of an arbitrage model. We regress 8.30-8.35 a.m. yield changes for each on-the-run Treasury security on surprises for the 108.30 a.m. macroeconomic announcements. Announcement surprises are divided by the mean absolute surprise for each announcement type to facilitate the comparison and interpretation of the coefficients and are defined to be zero on non-release days. We also include an announcement dummy variable as an explanatory variable, which equals one on days with any of the 10 announcements and zero otherwise. This variable captures the average yield changes, which may differ from zero due to announcement risk premia, found in daily data by Jones, Lamont and Lumsdaine (1998).

8 There are only 50 releases of leading indicators in our sample period due to the timing of this announcement near the turn of the month. 


\subsection{Regression estimates}

Least squares regression findings are reported in Table 3 and Figure 1. Table 3 reports the number of on-the-run Treasury yields for which the announcement surprise coefficients are significant at the 5\% level, as well as the regression coefficients themselves for the three-month bill, two-year note and 30year bond. Figure 1 plots the regression coefficients for all eight on-the-run Treasury yields against the mean durations of the corresponding securities. The dashed lines in Figure 1 delineate 95\% confidence intervals.

Table 3

Unconstrained impact of announcement surprises on Treasury yields

\begin{tabular}{|c|c|c|c|c|}
\hline Announcement & $\begin{array}{c}\text { No. of significant } \\
\text { coefficients }\end{array}$ & 3-month bill & 2-year note & 30-year bond \\
\hline \multirow[t]{2}{*}{ Intercept } & & 0.007 & 0.037 & 0.063 \\
\hline & & $(0.046)$ & $(0.038)$ & $(0.035)$ \\
\hline \multirow[t]{2}{*}{ Consumer price index } & 8 of 8 & $0.593^{*}$ & $1.472^{* * *}$ & $1.296^{* *}$ \\
\hline & & $(0.250)$ & $(0.246)$ & $(0.254)$ \\
\hline \multirow[t]{2}{*}{ Durable goods orders } & 8 of 8 & $1.275^{* * *}$ & $2.180^{* * *}$ & $1.170^{* *}$ \\
\hline & & $(0.235)$ & $(0.296)$ & $(0.168)$ \\
\hline \multirow[t]{2}{*}{ Gross domestic product } & 1 of 8 & 0.277 & 0.379 & 0.167 \\
\hline & & $(0.160)$ & $(0.224)$ & $(0.218)$ \\
\hline \multirow[t]{2}{*}{ Housing starts } & 8 of 8 & $0.670 * *^{2}$ & $1.406^{* * *}$ & $0.731^{* *}$ \\
\hline & & $(0.122)$ & $(0.174)$ & $(0.147)$ \\
\hline \multirow[t]{2}{*}{ Jobless rate } & 5 of 8 & $-0.939^{*}$ & $-1.318^{* *}$ & -0.158 \\
\hline & & $(0.382)$ & $(0.484)$ & $(0.239)$ \\
\hline \multirow[t]{2}{*}{ Leading indicators } & 4 of 8 & $0.411 * *^{2}$ & $0.525^{*}$ & $0.271^{*}$ \\
\hline & & $(0.141)$ & $(0.265)$ & $(0.137)$ \\
\hline \multirow{2}{*}{ Nonfarm payrolls } & 8 of 8 & $3.831^{* *}$ & $6.124^{* * *}$ & $2.679^{*}$ \\
\hline & & $(0.490)$ & $(0.669)$ & $(0.287)$ \\
\hline \multirow[t]{2}{*}{ Producer price index } & 8 of 8 & $0.768^{* *}$ & $1.879^{* *}$ & $1.738^{2}$ \\
\hline & & $(0.279)$ & $(0.267)$ & $(0.313)$ \\
\hline \multirow[t]{2}{*}{ Retail sales } & 8 of 8 & $0.582^{*}$ & $1.428^{* * *}$ & $0.766^{* *}$ \\
\hline & & $(0.226)$ & $(0.371)$ & $(0.250)$ \\
\hline \multirow[t]{2}{*}{ Trade balance } & 0 of 8 & -0.138 & 0.027 & -0.062 \\
\hline & & $(0.152)$ & $(0.156)$ & $(0.219)$ \\
\hline \multirow[t]{2}{*}{ Announcement dummy variable ${ }^{1}$} & 7 of 8 & -0.134 & $-0.410^{*}$ & $-0.242^{*}$ \\
\hline & & $(0.118)$ & $(0.160$ & $(0.101)$ \\
\hline Adjusted $\mathrm{R}^{2}$ & & 0.377 & 0.531 & 0.395 \\
\hline F-statistic ${ }^{2}$ & & $16.15^{* *}$ & $31.88^{* *}$ & $23.69^{* *}$ \\
\hline
\end{tabular}

Notes: Findings are reported from least squares regressions of Treasury yield changes on announcement surprises. The second column reports the number of on the run Treasury yields (out of a possible eight) significantly impacted by the surprise of the listed announcement at the 5\% level. The third, fourth and fifth columns report the regression coefficients for the three-month bill, two-year note, and 30-year bond, with heteroskedasticity consistent (White) standard errors in parentheses. Yield changes are measured in basis points and announcement surprises are measured as the actual surprises divided by the mean absolute surprises for each announcement type. The sample period is 1 July 1991 to 29 September 1995.

* Coefficient significantly different from zero at the 5\% level. ** Coefficient significantly different from zero at the $1 \%$ level.

${ }^{1}$ Dummy variable equal to one if any of the 10 announcements were made that day and zero otherwise. $\quad{ }^{2}$ Calculated using the heteroskedasticity consistent (White) covariance matrix. 
(a) Consumer price index

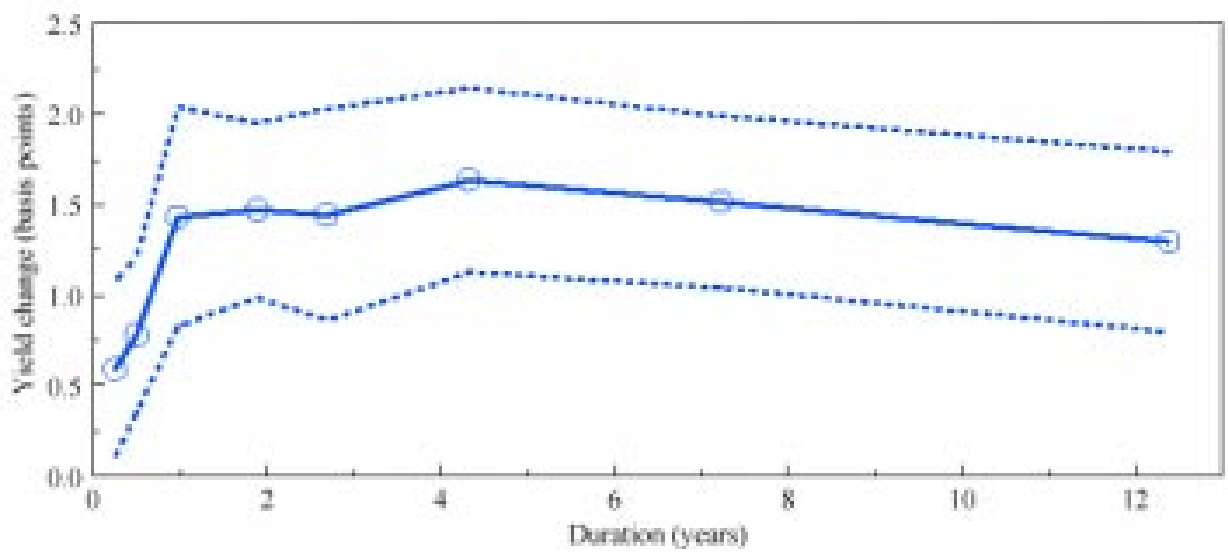

(b) Durable goods orders

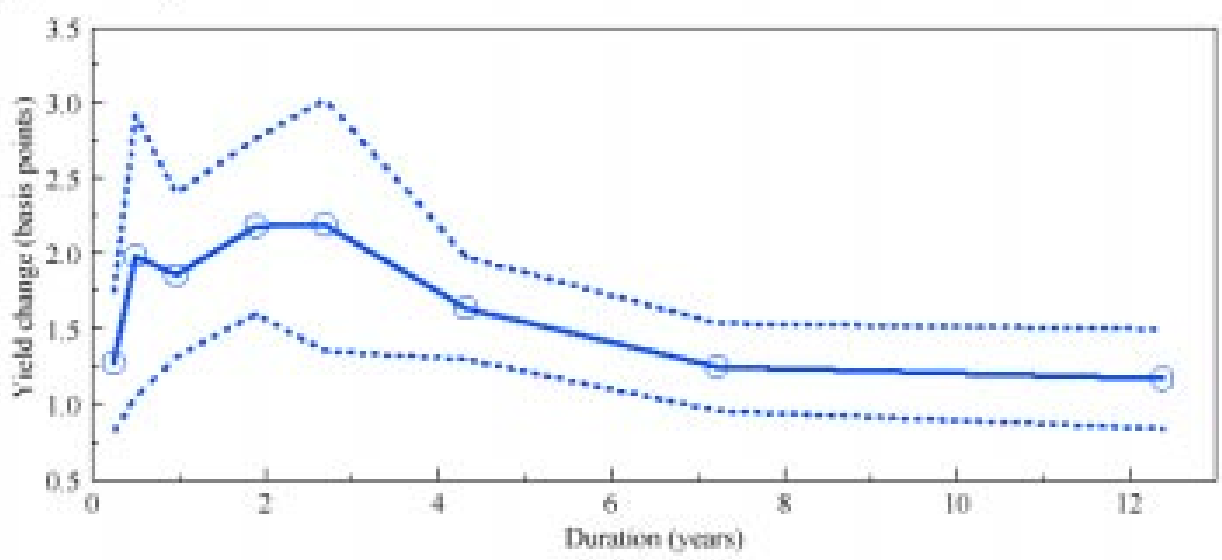

(c) Gross domestic product

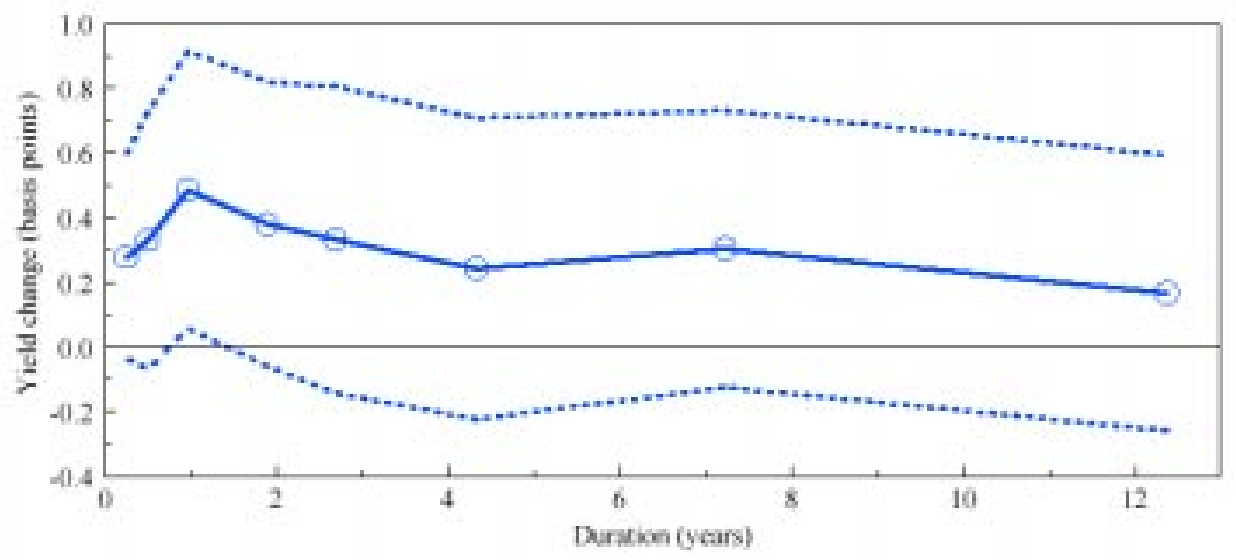

Fig. 1. Unconstrained impact of announcement surprises on Treasury yields. Coefficients are plotted from least squares regressions of Treasury yield changes on announcement surprises. Yield changes are measured in basis points and announcement surprises are measured as the actual surprises divided by the mean absolute surprises for each announcement type. Dashed lines delineate $95 \%$ confidence intervals based on heteroskedasticity-consistent (White) standard errors. The sample period is July 1, 1991 to September 29, 1995. 
(d) Housing starts

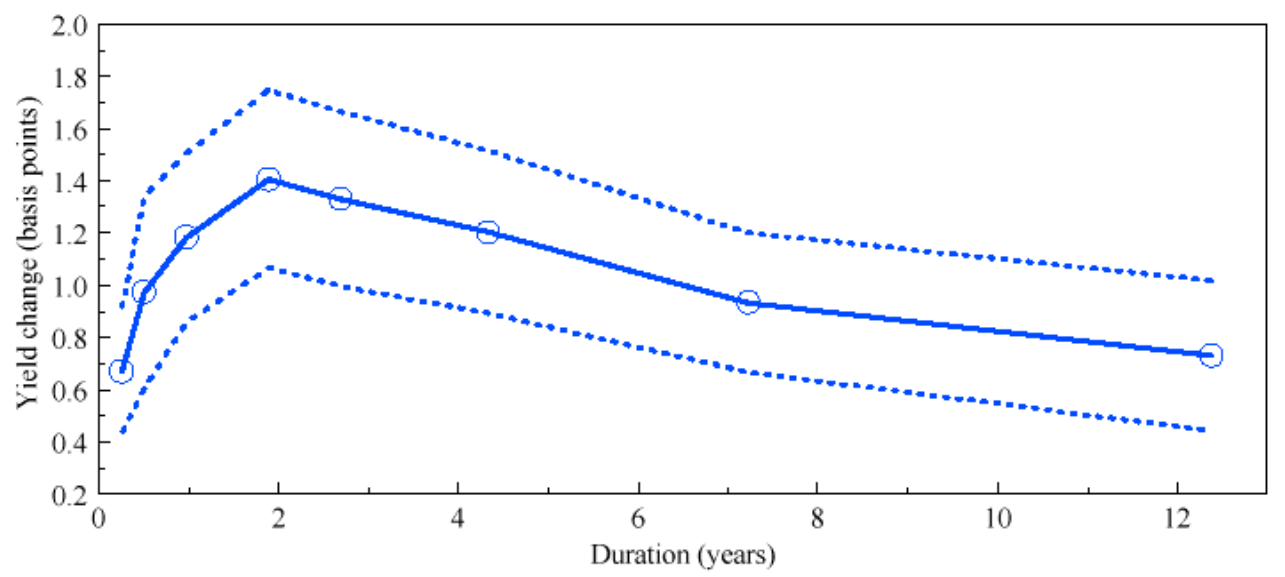

(e) Jobless rate

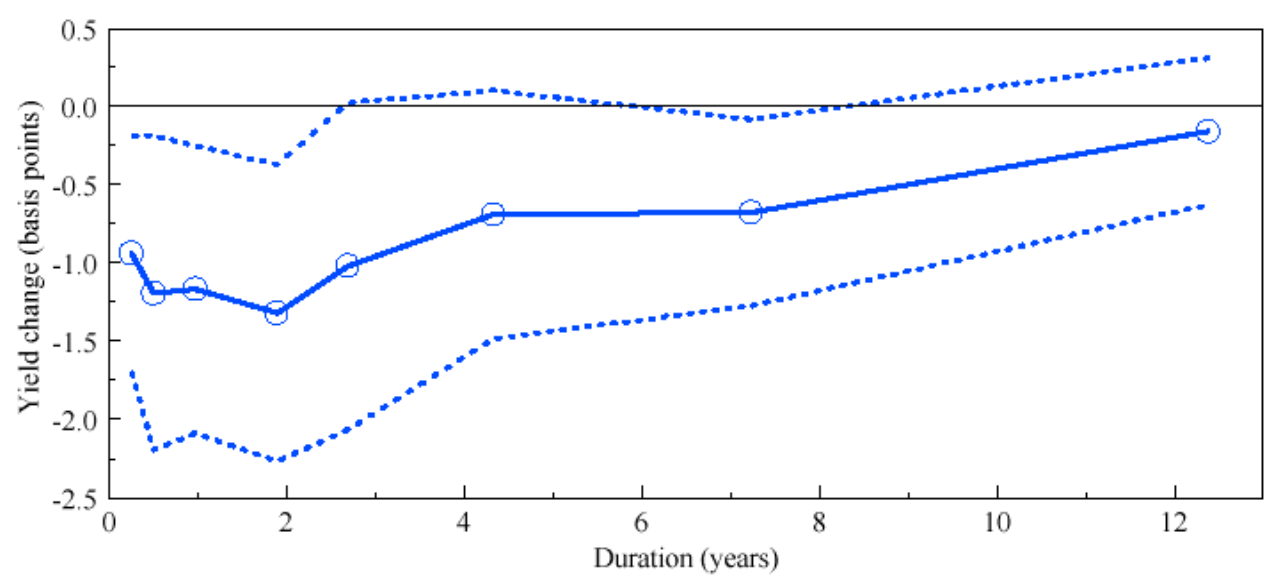

(f) Leading indicators

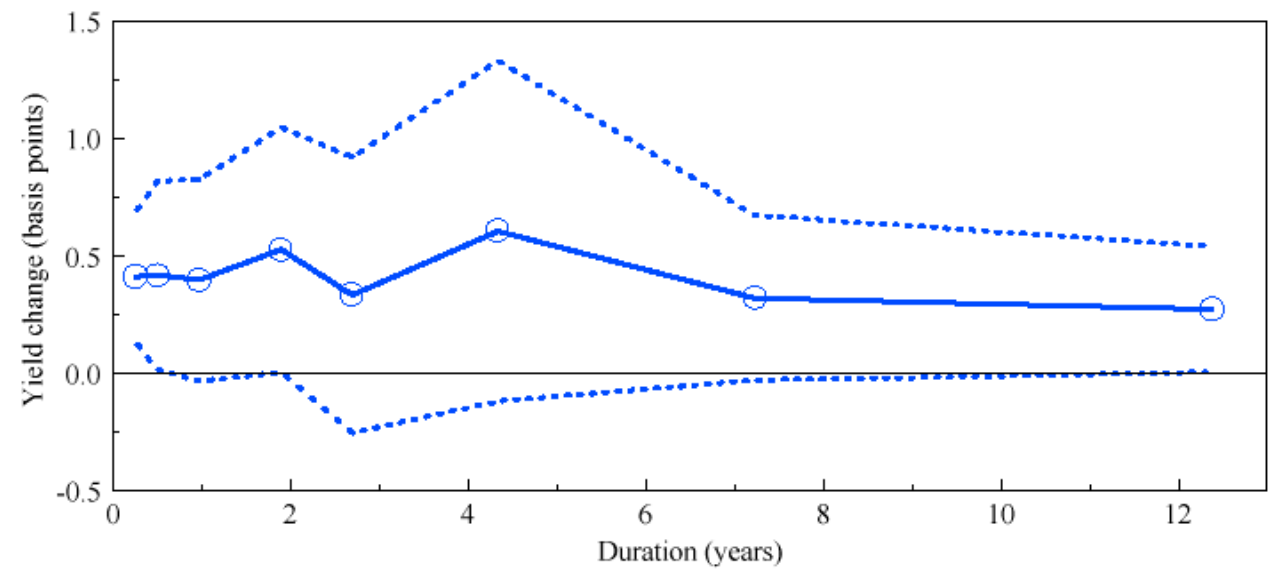

Fig. 1 (continued). 
(g) Nonfarm payrolls

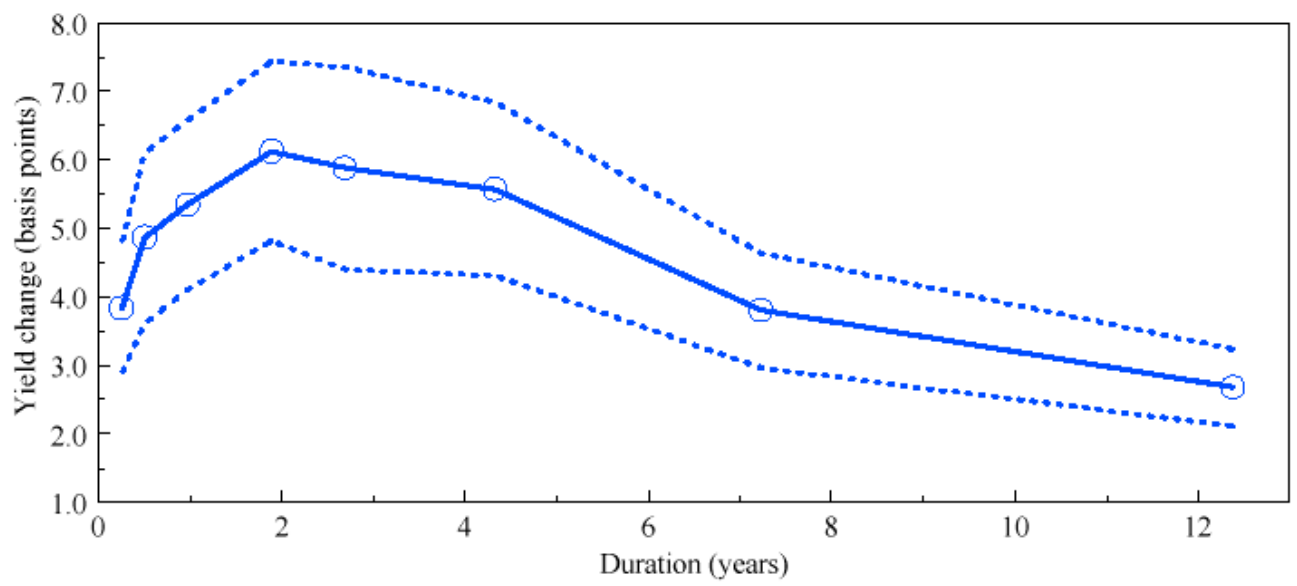

(h) Producer price index

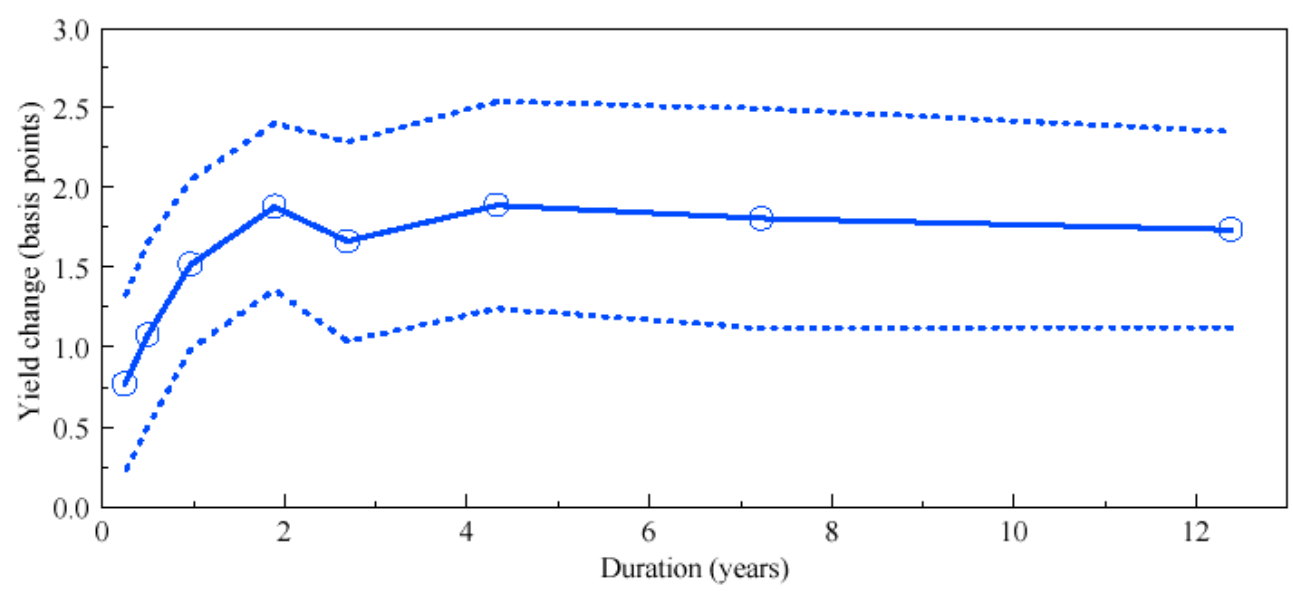

(i) Retail sales

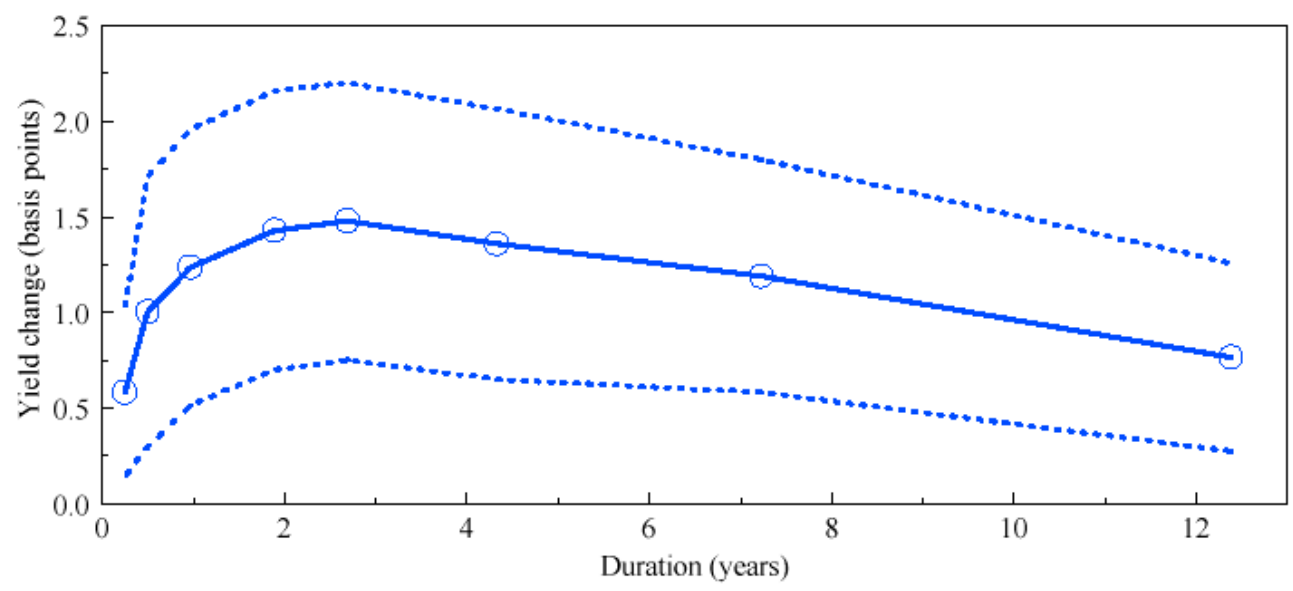

Fig. 1 (continued). 
(j) Trade balance

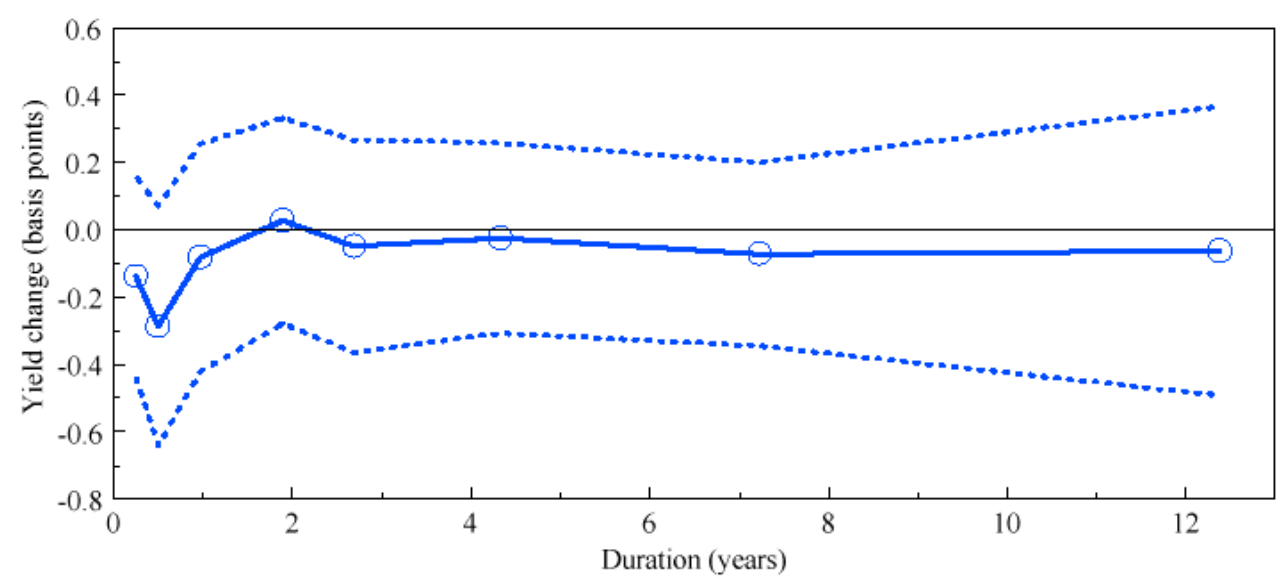

(k) Announcement dummy variable

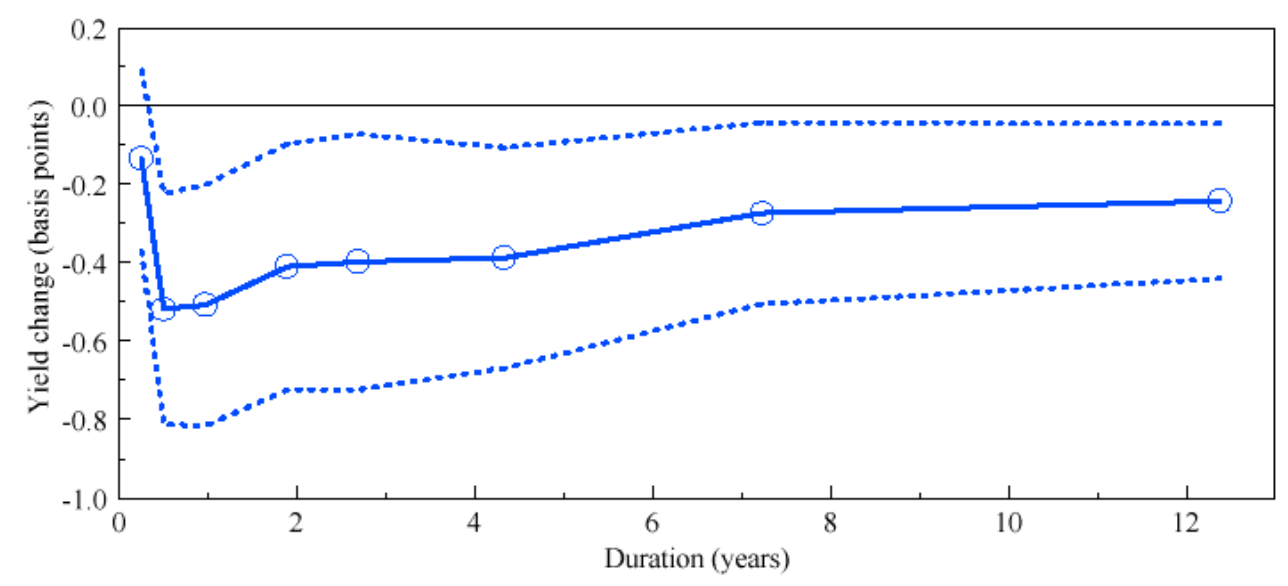

Fig. 1 (continued).

Table 3 and Figure 1 show that surprises of six of the 10 announcements significantly impact all eight on-the-run Treasury yields. The nonfarm payrolls number elicits the sharpest yield changes, followed (approximately) by durable goods orders, PPI, CPI, housing starts and retail sales. The only announcement that should have a negative relationship with yields, the jobless rate, significantly impacts five of the eight yields. Leading indicators significantly impacts four yields, GDP one yield, and trade balance no yields. The announcement dummy variable coefficient is significant for seven of the eight yields. Its negative values are consistent with the hypothesis that Treasury yields contain announcement risk premia that at least partially dissipate in the five minutes following an announcement.

The most striking findings of Table 3 and Figure 1 are the hump-shaped patterns of announcement effects. Macroeconomic announcement surprises evoke the sharpest yield reactions from intermediate-term Treasury securities. In Table 3, the magnitude of the coefficient for the two-year 
note exceeds that for the three-month bill and 30-year bond for every announcement that significantly impacts yields. Figure 1 shows that this finding is a general one, with yield effects of announcement surprises first rising and then falling with maturity, typically peaking with the two- or three-year note.

\subsection{Tests of announcement impact curves}

To formally compare announcement effects across the yield curve, we test four hypotheses for each of the announcements: (1) the coefficients are equal for all on-the-run securities; (2) the coefficient for the three-month bill is equal to that for the two-year note; (3) the coefficient for the two-year note is equal to that for the 30-year bond; and (4) the coefficient for the three-month bill is equal to that for the 30-year bond. To construct these tests, we first estimate a system of eight equations by GMM (one equation for each yield), using the announcement surprises as instruments. The orthogonality conditions are thus that the expectations of the residuals equal zero and that the expectations of the residuals times the announcement surprises equal zero. This application of GMM produces the same coefficients and standard errors as least squares and provides us with a covariance matrix that can be used to efficiently compare coefficients across equations.

Table 4 reports the p-values from Wald tests of the four hypotheses. The hypothesis that the yield effects of announcement surprises are equal across all maturities is rejected for eight of the 10 announcements. Not surprisingly, this hypothesis is not rejected for the two announcements that have

Table 4

Unconstrained model hypothesis tests

\begin{tabular}{|c|c|c|c|c|}
\hline Announcement & All eight equal & $\begin{array}{l}\text { 3-month bill }= \\
\text { 2-year note }\end{array}$ & $\begin{array}{l}\text { 2-year note }= \\
\text { 30-year bond }\end{array}$ & $\begin{array}{l}\text { 3-month bill = } \\
\text { 30-year bond }\end{array}$ \\
\hline Consumer price index & $0.000^{* *}$ & $0.000^{* *}$ & 0.379 & $0.006^{* *}$ \\
\hline Durable goods orders & $0.000 * *$ & $0.000 * *$ & $0.000^{* *}$ & 0.504 \\
\hline Gross domestic product & 0.543 & 0.580 & 0.233 & 0.541 \\
\hline Housing starts & $0.000^{* *}$ & $0.000^{* *}$ & $0.000^{* *}$ & 0.682 \\
\hline Jobless rate & $0.006^{* *}$ & 0.173 & $0.000^{* *}$ & $0.001^{* *}$ \\
\hline Leading indicators & $0.000^{* *}$ & 0.652 & 0.132 & 0.326 \\
\hline Nonfarm payrolls & $0.000^{* *}$ & $0.000^{* *}$ & $0.000^{* *}$ & $0.002^{* *}$ \\
\hline Producer price index & $0.000^{* *}$ & $0.000^{* *}$ & 0.486 & $0.000^{* *}$ \\
\hline Retail sales & $0.016^{*}$ & $0.001^{* *}$ & $0.004^{* *}$ & 0.240 \\
\hline Trade balance & 0.707 & 0.339 & 0.606 & 0.751 \\
\hline Annt. Dummy variable ${ }^{1}$ & $0.013^{*}$ & $0.027^{*}$ & 0.149 & 0.302 \\
\hline \multicolumn{5}{|c|}{$\begin{array}{l}\text { Notes: Findings are reported from various Wald tests on the coefficients from regressions of Treasury yield changes on } \\
\text { announcement surprises. The second column reports p-values from the test that the surprise of the listed announcement } \\
\text { has the same effect on yields for all eight on the run Treasury securities. The third through fifth columns report p-values } \\
\text { from the test that the surprise has the same effect on yields for the two indicated securities. All tests are conducted using } \\
\text { the heteroskedasticity consistent (White) covariance matrix. The sample period is } 1 \text { July } 1991 \text { to } 29 \text { September } 1995 \text {. }\end{array}$} \\
\hline \multicolumn{5}{|c|}{$\begin{array}{l}{ }^{*} \text { Hypothesis that coefficients are equal is rejected at the } 5 \% \text { level. }{ }^{* *} \text { Hypothesis that coefficients are equal is rejected at } \\
\text { the } 1 \% \text { level. }\end{array}$} \\
\hline${ }^{1}$ Dummy variable equal to & of the 10 announcem & nts were made tha & to 20 & \\
\hline
\end{tabular}


little or no impact on yields, GDP and trade balance (nor is any other hypothesis rejected for these two announcements). One of the subsequent two hypotheses is then rejected for seven of the eight announcements that have varying effects on yields, all expect leading indicators. Table 4 thus confirms statistically that announcement effects differ across the yield curve and that the patterns of announcement effects are hump-shaped.

Table 4 also confirms that the patterns of announcement effects differ somewhat by announcement type. Of the seven most important announcements, the hypothesis that the yield effects are the same for the two-year note and the 30-year bond is rejected for all but two: CPI and PPI. The hypothesis that the yield effects are the same for the three-month bill and the 30-year bond is rejected for all but three: durable goods orders, housing starts and retail sales. Of the four announcements for which this hypothesis is rejected, the coefficient on the three-month bill exceeds that for the 30 -year bond in two cases: jobless rate and nonfarm payrolls, and is less than that for the 30-year bond in two cases: CPI and PPI.

These differences in the patterns of announcement effects suggest three natural groupings of announcements that are possibly related to the nature of the information contained in the different announcements. The jobless rate and nonfarm payrolls numbers contain labour market information and exhibit hump-shaped announcement impact curves that dip lower for the 30-year bond than for the three-month bill. The CPI and PPI numbers both contain price level information and both show hump-shaped announcement impact curves that are relatively flat for longer-term securities. Finally, the durable goods orders, housing starts and retail sales numbers contain information on aggregate demand and show hump-shaped announcement impact curves that dip to a level close to that of the three-month bill for the 30-year bond.

Robustness tests show that these striking announcement impact curves are not attributable to the particular yields used in our analysis or to the narrow time interval over which we measure announcement effects (these additional results are available from the authors). Using bid yields in place of transaction yields, we uncover similar patterns of announcement effects with similar levels of significance. Expanding the time interval over which yield changes are measured from five minutes to 10 minutes results in similar coefficients and slightly higher standard errors as would be expected. With the window expanded to a full day, the standard errors increase so much that the announcement effects from important announcements such as CPI and PPI are insignificantly different from zero. The hump-shaped pattern is preserved for most announcements, however, and is virtually indistinguishable from the pattern calculated with five-minute yields for the most important number, nonfarm payrolls. One notable difference with daily yields is a sizable increase in measured announcement risk premia. This increase suggests that the risk premia found in daily data by Jones, Lamont and Lumsdaine (1998) may be attributable to both the price jump that occurs upon the release of a macroeconomic announcement and the heightened volatility that follows such an announcement. 


\subsection{Interpretation}

The most apparent implication of our regression findings is that the maturity pattern of announcement effects has changed since the late 1970s/early 1980s. Roley and Walsh (1985) and Cook and Hahn (1987) analyse the impact of weekly money supply announcements on the entire yield curve using daily data from October 1979 to October 1982. Both studies find an unambiguously downwardsloping announcement impact curve. ${ }^{9}$ Their explanation is that market participants expect the Federal Reserve to at least partially offset surprises in the money supply to bring it back to target. As the Fed is assumed to react to such surprises fairly quickly, the strongest announcement impact is felt at the short end of the yield curve, with the effect weakening progressively with longer maturities.

Hump-shaped announcement impact curves are also consistent with market participants focusing on a Fed reaction but in a policy regime that is qualitatively different from before. Instead of targeting the money supply, the Fed is now seen as targeting the federal funds rate, adjusting the rate only periodically and in measured steps towards an ultimate target. The Fed's behaviour is characterised by market participants as "cutting a cat's tail a little at a time" and by monetary economists as "interest rate smoothing" (e.g. Rudebusch (1995) and Clarida, Gali and Gertler (1999)). Upon the release of an announcement in this regime, market participants focus not only on the Fed's likely change to the target rate over the near term but also on the its ultimate target rate over the whole tightening or easing cycle. An announcement surprise can thereby induce hump-shaped responses, with sharper yield changes for intermediate maturities than for short ones.

These hump-shaped announcement impact curves complement recent work on the volatility structure. The volatility structure of interest rates is a critical issue in asset-pricing approaches that rely on the Ho and Lee (1986) and Heath, Jarrow and Morton (1992) framework. These approaches take as given the initial yield curve and solve for the distribution of the curve's future movements by specifying a volatility structure under the risk-neutral probability measure. While the volatility structure has generally been assumed to be downward-sloping, supported by analyses of earlier data, recent analyses suggest that the volatility curve is now hump-shaped (e.g. Amin and Morton (1994), Jeffrey (1998) and Dai and Singleton (1999)). Our findings show that this hump is at least partly attributable to yield changes that occur on the release of economic information.

Hump-shaped announcement impact and volatility curves have important implications for specifying affine-yield models. The most familiar such models extend Vasicek (1977) and Cox, Ingersoll and Ross (1985) by specifying stochastic processes for a number of independent mean-reverting factors. Longstaff and Schwartz (1992), Pearson and Sun (1994) and Duffie and Singleton (1997), for

9 Roley and Walsh (1985) examine the September 1977 to October 1979 period and find that the announcement impact curve first rises and then falls with maturity, peaking with the three-month bill. Cornell (1983) reports similar findings for pre- and post-October 1979. 
example, propose two-factor models, while Chen and Scott (1993) compare models with one, two, and three factors, each reverting to a fixed mean. These specifications tend to imply downward-sloping volatility curves, however, and can thus accommodate the Roley-Walsh and Cook-Hahn announcement impact curves but not the present hump-shaped ones. ${ }^{10}$ More recently, Jegadeesh and Pennacchi (1996), Balduzzi, Das and Foresi (1998) and Gong and Remolona (1997a and 1997b) have proposed models driven by an interaction between factors, with one factor serving as a stochastic mean to which another factor reverts. These specifications can generate hump-shaped volatility structures and are thus consistent with the present announcement curves. Dai and Singleton (1999) argue that specifications with an interaction between factors can explain important features of the volatility structure that earlier models could not.

A final implication of our regression analysis pertains to the differences in the patterns of announcement effects across announcement type. Such differences show that information is heterogeneous with respect to its impact on the term structure. Such heterogeneity supports our approach of looking at the term structure's response to particular types of information and demonstrates the usefulness of high-frequency data in isolating such responses.

\section{An affine-yield model of announcement effects}

The effects of announcements on the yield curve may be regarded as the result of market participants' revised expectations about the course of interest rates. This means that the effects on different maturities are not in fact independent but rather arise from a common expectations process. Vasicek (1977) and Cox, Ingersoll and Ross (1985) exploit arbitrage conditions to derive the precise links between such a yield curve and a one-factor stochastic process. Duffie and Kan (1996) generalise these results to multiple factors within the affine-yield class of models. In such models, announcement surprises may be viewed as giving rise to factor shocks and the effects on yields may be interpreted as factor loadings implied by underlying factor processes.

In this section, we specify an affine-yield model that will allow us to jointly estimate announcement effects for different maturities and thus infer the parameters describing the underlying expectations processes. The parameters provide an interpretation of the way announcements affect interest rate expectations and allow a comparison of these effects across types of announcements. We specify the model so that it can accommodate the hump-shaped announcement impact curves found in the previous section. This specification involves reversion by one factor to another, as in Jegadeesh and

\footnotetext{
${ }^{10}$ As will be apparent in the discrete-time model specified in the next section, independent mean-reverting factors lead to downward-sloping factor loadings and thus to a downward-sloping volatility curve. In continuous time models, however, it is possible for such factors to produce a hump in the loadings.
} 
Pennacchi (1996), Balduzzi, Das and Foresi (1998), Gong and Remolona (1997a and 1997b) and Dai and Singleton (1999).

\subsection{The pricing kernel}

Following Backus and Zin (1994) and Campbell, Lo and MacKinlay (1997), we specify the model in discrete time. We denote by $P_{n t}$ the price of an $n$-month zero-coupon bond at time $t$. The intertemporal asset pricing equation specifies the bond's price as $P_{n t}=E_{t}\left(M_{t+1} P_{n-1, t+1}\right)$, where $M_{t+1}$ is the stochastic discount factor and $P_{n-1, t+1}$ is the same bond's price a month later. Assuming the discount factor is conditionally lognormal, we can take logs to write

$$
p_{n t}=E_{t}\left(m_{t+1}+p_{n-1, t+1}\right)+\frac{1}{2} \operatorname{Var}_{t}\left(m_{t+1}+p_{n-1, t+1}\right)
$$

with lower case letters representing logarithms. The bond's yield is given by $y_{n t}=-p_{n t} / n$. We can then model bond yields by specifying the stochastic process for $m_{t+1}$, a process called the pricing kernel.

We specify a pricing kernel that is driven by expectations about macroeconomic fundamentals. To form expectations, market participants rely materially on information in macroeconomic announcements. We associate with each type of announcement $i$ a factor $x_{i t}$ to represent an expectation process affecting interest rates. A particular announcement type may be made up of one announcement, or it may be made up of two or more announcements that are thought to affect market participants views in a similar way (e.g. CPI and PPI). While announcement types are indexed with subscript $i$, announcements within a given type are indexed with subscript $j$. For $K$ different types of announcements, we write the pricing kernel as

$$
-m_{t+1}=\sum_{i=1}^{K} x_{i t}+w_{t+1}
$$

where $w_{t+1}$ is a shock to the discount factor that is related to risks arising from shocks in the factors.

\subsection{Expectations processes within a month}

To capture the expectational impact of announcements at high frequencies, we first specify the factors' stochastic processes over intervals that can be as short as five minutes. We divide a given month into $N$ intervals and let $h \equiv 1 / N$. We then specify the change in the factor $x_{i t}$ from time $s$ to time $s+h$ as

$$
x_{i, s+h}-x_{i s}=\left(1-\phi_{i}^{h}\right)\left(z_{i s}-x_{i s}\right)+\varepsilon_{i, s+h}
$$


where $1-\phi_{i}{ }^{h}$ is the reversion rate towards a mean $z_{i s}$, and $\varepsilon_{i, s+h}$ is a shock to the factor. A stationary expectations process implies that $\phi_{i}$ is less than one. We assume that the shock has two independent components:

$$
\varepsilon_{i, s+h}=\sqrt{h} \varepsilon_{i, s+h}^{R}+\sum_{j} I_{j i s} \varepsilon_{j i, s+h}^{A}
$$

The component $\sqrt{h} \varepsilon_{i, s+h}^{R}$ represents an i.i.d. regular shock that arises in every interval, while $\sum_{j} I_{j i s} \varepsilon_{j i, s+h}^{A}$ represents shocks from announcements. The variable $I_{j i s}$ is an indicator that accounts for the fact that announcements are released only once a month. If $s_{j i}$ is an announcement's release time, then $I_{j i s}=1$ for $s=s_{j i}$ and $I_{j i s}=0$ otherwise. In most cases, the announcement shock $\varepsilon_{j i, s_{i}+h}^{A}$ will be much larger than the regular shocks $\sqrt{h} \varepsilon_{i, s+h}^{R}$.

A critical feature of the model is the stochastic nature of the factor's mean. We specify the stochastic process for this mean as

$$
z_{i, s+h}-z_{s}=\left(1-\theta_{i}^{h}\right)\left(\mu_{i}-z_{s}\right)+\eta_{i, s+h}
$$

where $1-\theta_{i}{ }^{h}$ is the reversion rate to a fixed mean $\mu_{i}$, and $\eta_{i, s+h}$ is a shock. We expect $\theta_{i}$ to be less than one but closer to one than $\phi_{i}$, so that the factor may have a chance to "catch up" to its mean. The shock to the mean also consists of two independent components,

$$
\eta_{i, s+h}=\sqrt{h} \eta_{i, s+h}^{R}+\sum_{j} I_{j i s} \eta_{j i, s+h}^{A}
$$

where $I_{j i s}$ is the same indicator as in (4) and superscripts $R$ and $A$ indicate regular shocks and announcement shocks respectively. Finally, we assume that the shocks to the mean are proportional to those to the factor:

$$
\eta_{j i, s+h}^{A}=\gamma_{i} \varepsilon_{j i, s+h}^{A}
$$

where $\gamma_{i}$ measures the relative shock size.

\subsection{Expectations processes over a month}

To derive the stochastic processes for expectations over a month, we simply add up the changes within a month as given by (3) and (5). Because the stochastic mean reverts to a fixed mean, it is straightforward to aggregate its changes:

$$
z_{i, t+1}-z_{i t}=\sum_{k=1}^{N}\left(z_{i, t+k h}-z_{i, t+k h-h}\right)=\left(1-\theta_{i}\right)\left(\mu_{i}-z_{i t}\right)+v_{i, t+1}
$$


using the fact that $\theta_{i}^{h N}=\theta_{i}$ and letting $v_{i, t+1} \equiv \sum_{k=1}^{N} \eta_{i, t+k h}$. The aggregate monthly shock $v_{i, t+1}$ then has the variance $\sigma_{i v}{ }^{2} \equiv \operatorname{Var}\left(\eta_{i, s+h}^{R}\right)+\sum_{j} \operatorname{Var}\left(\eta_{j i, s+h}^{A}\right)$, assuming that announcement shocks are uncorrelated across different announcements.

In the case of the factor $x_{i t}$, the stochastic process can be characterised as

$$
x_{i, t+1}-x_{i t}=\sum_{k=1}^{N}\left(x_{i, t+k h}-x_{i, t+k h-h}\right) \approx\left(1-\phi_{i}\right)\left(z_{i t}-x_{i t}\right)+u_{i, t+1}
$$

with $\phi_{i}{ }^{h N}=\phi_{i}$ and $u_{i, t+1} \equiv \sum_{k=1}^{N} \varepsilon_{i, t+k h}$. The second equality in (8) is no longer strict, because the expression does not account for the fact that $z_{i t}$ is reverting to $\mu_{i}$ at the same time as $x_{i t}$ is moving towards $z_{i t}$. However, given the likely values for $\phi_{i}$ and $\theta_{i}$, the approximation in (8) should be quite good. The aggregate shock $u_{i, t+1}$ has variance $\sigma_{i u}{ }^{2} \equiv \operatorname{Var}\left(\varepsilon_{i, s+h}^{R}\right)+\sum_{j} \operatorname{Var}\left(\varepsilon_{j i, s+h}^{A}\right)$, and from (7), $\operatorname{Var}\left(\eta_{j i, s+h}^{A}\right)=\gamma_{i}{ }^{2} \operatorname{Var}\left(\varepsilon_{j i, s+h}^{A}\right)$.

\subsection{The pricing kernel and affine yields}

Equations (2), (8) and (9) provide the following equations for the pricing kernel

$$
\begin{aligned}
& -m_{t+1}=\sum_{i=1}^{K} x_{i t}+w_{t+1} \\
& x_{i, t+1}=\left(1-\phi_{i}\right) z_{i t}+\phi_{i} x_{i t}+u_{i, t+1}, \text { for } i=1, \ldots, K \text { and } \\
& z_{i, t+1}=\left(1-\theta_{i}\right) \mu_{i}+\theta_{i} z_{i t}+v_{i, t+1}, \text { for } i=1, \ldots, K
\end{aligned}
$$

In general, the pricing kernel's shock depends on all the factors' shocks:

$$
w_{t+1}=\sum_{i=1}^{K}\left(\beta_{i} u_{i, t+1}+\lambda_{i} v_{i, t+1}\right)
$$

where $\beta_{i}$ and $\lambda_{i}$ are interpreted as prices of risk.

By substituting equations (10) to (13) into (1), it can be shown that yields are affine functions of $2 K$ factors:

$$
y_{n t}=\frac{1}{n}\left(A_{n}+\sum_{i=1}^{K} B_{i n} x_{i t}+\sum_{i=1}^{K} C_{i n} z_{i t}\right)
$$

where the stochastic means $z_{i t} \mathrm{~s}$ are now considered to be factors just as the $x_{i t} \mathrm{~s}$ are factors. The factor loadings follow the recursive equations

$$
B_{i n}=1+\phi_{i} B_{i, n-1}, \text { for } i=1, \ldots, K \text { and }
$$




$$
C_{i n}=\theta_{i} C_{i, n-1}+\left(1-\phi_{i}\right) B_{i, n-1}, \text { for } i=1, \ldots, K
$$

while the constant term follows

$$
A_{n}=A_{n-1}+\sum_{i=1}^{K}\left(1-\theta_{i}\right) \mu_{i} C_{i, n-1}-\frac{1}{2} \sum_{i=1}^{K}\left(\beta_{i}+B_{i, n-1}\right)^{2} \sigma_{i u}{ }^{2}-\frac{1}{2} \sum_{i=1}^{K}\left(\lambda_{i}+C_{i, n-1}\right)^{2} \sigma_{i v}{ }^{2}
$$

all of which serve to impose the condition of no arbitrage. Given our homoskedastic volatilities, the factor loadings admit closed-form solutions

$$
\begin{aligned}
& B_{i n}=\frac{1-\phi_{i}{ }^{n}}{1-\phi_{i}}, \text { for } i=1, \ldots, K \text { and } \\
& C_{i n}=\frac{1-\theta_{i}{ }^{n-1}}{1-\theta_{i}}+\theta_{i}{ }^{n-1}\left[1-\frac{1-\left(\phi_{i} / \theta_{i}\right)^{n}}{1-\left(\phi_{i} / \theta_{i}\right)}\right], \text { for } i=1, \ldots, K
\end{aligned}
$$

We normalise with $p_{0 t}=0$, since a bond trades at par at maturity. It then follows that the short rate is $\left.y_{1 t}=\sum_{i=1}^{K} \mid x_{i t}-\frac{1}{2}\left(\beta_{i}^{2} \sigma_{i u}^{2}+\lambda_{i}^{2} \sigma_{i v}^{2}\right)\right]$, where $A_{1}=0, B_{i 1}=1$ and $C_{i 1}=0$ for $i=1, \ldots, K$.

At this point, we note two important aspects of the model. First, the $x_{i t}$ factors represent expectations that drive current changes in the short rate, while the $z_{i t}$ factors represent expectations that drive the expected future path of this rate. Second, the factor loading $B_{\text {in }} / n$ declines monotonically with bond maturity $n$ and by itself will produce a downward-sloping volatility curve. The loading $C_{i n} / n$ rises before it falls, which is the property that can generate a hump-shaped volatility curve as well as humpshaped curves of announcement effects.

\subsection{Predicted announcement effects}

To model the effects of macroeconomic announcements on the yield curve, we treat the announcement surprises as sources of factor shocks. Specifically, we let the announcement shock to $x_{i t}$ be $\varepsilon_{j i t}^{A} \equiv \alpha_{j i} s_{j i t}$, where $s_{j i t}$ is the measured surprise in the $j$ th announcement of type $i$ released in month $t$ and $\alpha_{j i}$ is a scaling parameter to transform surprises into the appropriate factor units. The announcement shock to $z_{i t}$ is then $\eta_{j i t}^{A}=\gamma_{i} \alpha_{j i} s_{j i t}$. Hence, for an $n$-maturity bond and for the narrow interval $h$ immediately after an announcement's release, equations (3), (5) and (14) of the model predict a yield change of

$$
y_{n, s_{j i} i}+h, t-y_{n, s_{j i}, t}=\frac{1}{n}\left(B_{i n}+\gamma_{i} C_{i n}\right) \alpha_{j i} s_{j i t}
$$

where the loadings $B_{i n}$ and $C_{i n}$ are determined by the parameters $\phi_{i}$ and $\theta_{i}$. 
The observed yield change may also reflect a premium for announcement risk, as found by Jones, Lamont and Lumsdaine (1998), as well as measurement error. The observed yield change is then

$$
\Delta y_{n j i t}=\frac{1}{n}\left(B_{i n}+\gamma_{i} C_{i n}\right) \alpha_{j i} s_{j i t}-\alpha_{j i} \rho_{i n}+e_{n j i t}
$$

where the term $\alpha_{j i} \rho_{i n}$ represents an announcement risk premium that depends on the announcement and the bond's maturity and $e_{n j i t}$ is measurement error that is orthogonal to $s_{j i t} \cdot{ }^{11}$

\section{Estimating the affine-yield model}

To fit our affine-yield model to the announcement effects, we use the generalised method of moments (GMM) procedure of Hansen (1982). The procedure identifies parameter values that minimise (with respect to a certain weighting matrix) the errors between actual and estimated announcement effects, $e_{n j i t}=\Delta y_{n j i t}-\frac{1}{n}\left(B_{i n}+\gamma_{i} C_{i n}\right) \alpha_{j i} s_{j i t}+\alpha_{j i} \rho_{i n}$. The estimated announcement effects are thus constrained to be consistent with the factor loadings implied by the model, where the loadings are functions of parameters describing interest rate processes perceived by bond market participants.

For a given month $t$, we put together in a single vector the errors for bond maturities $n$ from all announcements $j$ of a given type $i$. Suppressing some subscripts, we express this error vector as $\mathbf{e}_{t}=\mathbf{e}\left(\Delta \mathbf{y}_{t}, \mathbf{s}_{t}, \theta\right)$, where $\Delta \mathbf{y}_{t}$ consists of yield changes upon announcements for eight bond maturities, $\mathbf{s}_{t}$ consists of measured surprises for the announcements and $\theta$ consists of parameters describing the expectations process $\left(\phi_{i}, \theta_{i}\right.$ and $\left.\gamma_{i}\right)$, scale parameters for the various announcements $\left(\alpha_{j i}\right)$ and risk premia parameters for the different bond maturities $\left(\rho_{i n}\right)$.

\subsection{Orthogonality conditions}

The model states that there is a true parameter vector $\theta_{0}$ for which $\mathbf{e}\left(\Delta \mathbf{y}_{t}, \mathbf{s}_{t}, \theta_{0}\right)$ is orthogonal to a vector of instruments $\mathbf{h}_{t}$. One of our instruments is a constant, so that an orthogonality condition is $E\left[\mathbf{e}\left(\Delta \mathbf{y}_{t}, \mathbf{s}_{t}, \theta_{0}\right)\right]=0$. Our other instruments are the announcement surprises themselves. Announcement surprises are ideal instruments for our analysis because they are both related to yield changes and exogenous. However, the relationship with yield changes should hold only for

11 While there are several risk premia in the model, each is constant from one month to the next. It is possible to model time-varying risk premia (e.g. by specifying square-root processes), but such time variation is difficult to estimate with the high-frequency data we focus on. 
announcements released at that time. PPI surprises, for example, are excellent instruments for yield changes at the time of PPI announcements, but not for yield changes at the time of CPI announcements, which are released one to seven days later. Our orthogonality conditions therefore involve only one announcement at a time:

$$
E\left[s_{j t} \otimes \mathrm{e}\left(\Delta \mathbf{y}_{j t}, \mathbf{s}_{j t}, \theta_{0}\right)\right]=0
$$

where $\otimes$ denotes the Kronecker product.

The general condition is then:

$$
E\left\lfloor\mathbf{h}_{j t} \otimes \mathbf{e}\left(\Delta \mathbf{y}_{j t}, \mathbf{s}_{j t}, \theta_{0}\right)\right]=0
$$

where $\mathbf{h}_{j t} \equiv\left\lfloor s_{j t}\right\rfloor$. Setting $\mathbf{f}_{j t}(\theta) \equiv \mathbf{h}_{j t} \otimes \mathrm{e}\left(\Delta \mathbf{y}_{j t}, \mathbf{s}_{j t}, \theta\right)$, the condition is simplified to $E\left[\mathbf{f}_{j t}\left(\theta_{0}\right)\right]=0$, for $j=1, \ldots, J$.

\subsection{The weighting matrix}

To construct the sample counterpart of the orthogonality condition (24), we define the vector

$$
\mathbf{g}_{T}(\theta) \equiv \frac{1}{T} \sum_{t=1}^{T} \mathbf{f}_{t}(\theta)
$$

where $\mathbf{f}_{t}$ is now a vector consisting of $\mathbf{f}_{1 t}, \ldots, \mathbf{f}_{J t}$ for the $J$ announcements of a given type and $T$ is the number of months in our sample. The GMM procedure chooses the parameter vector $\hat{\theta}$ to minimise the quadratic form

$$
J_{T}(\theta) \equiv \mathbf{g}_{T}(\theta) \mathbf{W}_{T} \mathbf{g}_{T}(\theta)
$$

where $\mathbf{W}_{T}$ is a positive definite weighting matrix. To obtain a unique solution to the minimisation problem, the system must be overidentified, that is, $\mathbf{g}_{T}(\theta)$ must contain more elements than $\theta$ does.

The optimal weighting matrix is one that minimises the asymptotic covariance matrix of the parameter estimate $\hat{\theta}$. Hansen (1982) shows that this weighting matrix is any positive scalar times the inverse of the matrix

$$
\mathbf{S} \equiv \lim _{T \rightarrow \infty} \operatorname{Var}\left[\sqrt{T} \mathbf{g}_{T}\left(\theta_{0}\right)\right\rfloor
$$

To estimate $\mathbf{S}$, we start by using the identity matrix for $\mathbf{W}_{T}$ to minimise the quadratic form (26) and get an initial estimate for $\hat{\theta}$. We then obtain a sample estimate $\mathbf{S}(\hat{\theta})$ and repeat the procedure after substituting $\mathbf{W}_{T}=\mathbf{S}(\hat{\theta})^{-1}$. We iterate the procedure until the parameter estimates converge. 


\section{$5.3 \quad$ Test statistics}

If the model holds, our estimate $\hat{\theta}$ will bring the objective function $\mathbf{J}_{T}(\hat{\theta})$ close to zero. We test the model's specification by means of Hansen's J-statistic, $T \mathbf{J}_{T}(\hat{\theta})$, which is asymptotically distributed $\chi^{2}$ with degrees of freedom equal to the number of overidentifying restrictions. The number of overidentifying restrictions equals the number of orthogonality conditions minus the number of parameters.

To evaluate the precision of individual parameter estimates, we derive the matrix of partial derivatives

$$
\mathbf{D}_{T}(\theta) \equiv \frac{\partial \mathbf{g}_{T}(\theta)}{\partial \theta}
$$

The fact that the factor loadings $B_{i n}$ and $C_{i n}$ have the closed-form solutions (18) and (19) allows us to compute analytical derivatives for $\mathbf{D}_{T}$. We then construct an estimate of the covariance matrix for $\hat{\boldsymbol{\theta}}$ :

$$
\mathbf{V}_{T} \equiv\left(\mathbf{D}_{T}{ }^{\prime} \mathbf{W}_{T} \mathbf{D}_{T}\right)^{-1}
$$

The square roots of the diagonal elements of $\mathbf{V}_{T}$ are the standard errors for our parameters.

\section{$5.4 \quad$ Implementation}

The above GMM procedure is fit to groups of one or more announcements of a given type $i$ that are thought to have similar expectations processes. The yield changes are the same as those used in Section 3: the differences between the last yields before an announcement and the first yields at least five minutes after an announcement. Maturities, $n$, for the eight on-the-run securities are fixed at the average durations (in months) of the securities during our sample period, as reported in Table 1. Announcement surprises are measured as the differences between the actual and the expected numbers, as in Section 3.

\section{Affine-yield model estimates}

We calculate model-constrained estimates of announcement effects for each of three groups comprising six macroeconomic announcements: (1) a labour market expectations process is estimated with nonfarm payrolls; (2) a price level expectations process is estimated with CPI and PPI; and (3) an aggregate demand expectations process is estimated with durable goods orders, housing starts and retail sales. The six announcements are those that significantly impact yields of all eight on-the-run Treasury securities in the least squares regressions in Section 3. Each of the three groups is formed by those announcements identified in Section 3 as having similar patterns of effects. The announcements 
within each group also happen to be related in information content. As a robustness test, we also estimate the model individually for each of the six announcements.

\subsection{Parameter estimates}

We report parameter estimates for the three groups of announcements in Table 5 (and parameter estimates for the individual announcements in Appendix A). The estimates suggest certain similarities in the expectations processes of the three groups. First, the persistence parameters are significantly different from zero but insignificantly different from one for all three groups. Second, the stochastic mean parameter is larger than the short-rate parameter for all three groups, suggesting shocks to the mean that last longer than shocks to the short rate. Third, the relative shock size parameter is greater than one for all three groups, indicating shocks to the mean that are larger than shocks to the short rate. It is this last feature, in which expectations of the future interest rate target seem to dominate expectations of more immediate movements in the short-term rate, that generates the humps in the announcement impact curves. Lastly, all eight risk premia parameters are insignificantly different from zero for all three groups.

Table 5 also portrays certain differences in the expectations processes of the three groups of announcements. The persistence parameter for the short rate varies from 0.85 for aggregate demand announcements to 0.90 for price level announcements and 0.94 for the labour market announcement. Table 6 reports the corresponding average half lives. The parameter estimates imply that the aggregate demand announcements elicit shocks to the short rate with an average half life of 4.2 months, versus 6.7 months for the price level announcements and 10.9 months for the labour market announcement.

The persistence parameter for the stochastic mean ranges from 0.966 for the labour market announcement to 0.986 for the aggregate demand announcements and 0.995 for the price level announcements. The corresponding average half lives are 20.1 months for the labour market announcement, 50.0 months for the aggregate demand announcements and 149.4 months for the price level announcements. Price level announcements thus seem to induce lasting revisions to a future interest rate target, particularly when compared to the labour market announcement. This finding is consistent with the least squares regression findings of Section 3, in which CPI and PPI surprises elicit sharper yield changes in the 30-year bond than in short-term securities whereas nonfarm payrolls surprises elicit sharper yield changes in short-term securities than in the 30-year bond.

Differences across groups of announcements are also evident in the J-statistics of Table 5, which test the model specification assumptions. For the labour market announcement, the J-statistic implies a pvalue of 0.18 , suggesting a model that is well specified. The p-values for the price level and aggregate demand announcements are just 0.03 and 0.00 respectively, suggesting a model that is not completely 
Table 5

Constrained impact of announcement surprises on Treasury yields

\begin{tabular}{|c|c|c|c|c|c|c|}
\hline \multirow{2}{*}{$\begin{array}{l}\text { Parameters } \\
\text { Short-rate persistence } \phi\end{array}$} & \multicolumn{2}{|c|}{$\begin{array}{l}\text { Labour market } \\
\text { announcement }\end{array}$} & \multicolumn{2}{|c|}{$\begin{array}{c}\text { Price level } \\
\text { announcements }\end{array}$} & \multicolumn{2}{|c|}{$\begin{array}{l}\text { Aggregate demand } \\
\text { announcements }\end{array}$} \\
\hline & 0.938 & $(0.264)$ & 0.901 & $(0.235)$ & 0.847 & $(0.148)$ \\
\hline Stochastic mean persistence $\theta$ & 0.966 & $(0.106)$ & 0.995 & $(0.009)$ & 0.986 & $(0.008)$ \\
\hline Relative shock size $\gamma$ & 3.626 & $(4.509)$ & 4.167 & $(7.573)$ & 3.071 & $(1.415)$ \\
\hline \multicolumn{7}{|l|}{ Scale parameters $\alpha_{j}$} \\
\hline Consumer price index & & & 0.413 & $(0.884)$ & & \\
\hline Producer price index & & & 0.644 & $(1.658)$ & & \\
\hline Durable goods orders & & & & & 0.788 & $(0.452)$ \\
\hline Housing starts & & & & & 0.553 & $(0.448)$ \\
\hline Retail sales & & & & & 0.780 & $(0.401)$ \\
\hline \multicolumn{7}{|l|}{ Risk premia $\rho_{n}$} \\
\hline 3-month bill & -0.046 & $(1.157)$ & 0.443 & $(2.332)$ & -0.269 & $(0.556)$ \\
\hline 6-month bill & 0.164 & $(1.241)$ & 1.196 & $(4.216)$ & 0.461 & $(0.542)$ \\
\hline 1-year bill & 0.186 & $(1.349)$ & 1.580 & $(5.419)$ & 0.831 & $(0.827)$ \\
\hline 2-year note & -0.062 & $(1.444)$ & 1.472 & $(5.596)$ & 1.294 & $(0.840)$ \\
\hline 3-year note & -0.139 & $(1.570)$ & 0.524 & $(3.958)$ & 0.375 & $(0.845)$ \\
\hline 5 -year note & -0.044 & $(1.280)$ & 0.794 & $(4.355)$ & 0.774 & $(0.924)$ \\
\hline 10-year note & -0.083 & $(1.029)$ & 0.408 & $(3.243)$ & 0.899 & $(0.870)$ \\
\hline 30-year bond & -0.021 & $(0.752)$ & 0.228 & $(2.475)$ & 0.553 & $(0.612)$ \\
\hline J-statistic & 6.197 & & 32.212 & & 256.255 & \\
\hline Overidentifying restrictions & 4 & & 19 & & 34 & \\
\hline p-value & 0.185 & & 0.030 & & 0.000 & \\
\hline \multicolumn{7}{|c|}{$\begin{array}{l}\text { GMM parameter estimates are reported for a two-factor affine-yield model that is fit to announcement surprises and } \\
\text { Treasury yield changes for each of three groups of announcements (the model is specified in equations (10) to (21)). The } \\
\text { announcement groups are: labour market (nonfarm payrolls), price level (consumer price index and producer price index), } \\
\text { and aggregate demand (durable goods orders, housing starts, and retail sales). Standard errors are reported in parentheses. } \\
\text { The sample period is } 1 \text { July } 1991 \text { to } 29 \text { September } 1995 \text {. }\end{array}$} \\
\hline
\end{tabular}

consistent with the data. This inconsistency may arise from a difficulty in fitting a short-rate response that is close to zero. The model may also be misspecified because the grouped announcements do not truly give rise to fundamentally similar revisions in expectations. This possibility leads us to estimate the model for the announcements individually and to report the parameter estimates in Appendix A. The individual parameter estimates are qualitatively similar to those of the grouped announcements and the J-statistics indicate that the model is well specified for five of the six announcements. Half lives derived from the individual announcement estimates are reported in Appendix B.

\subsection{Implied announcement impact curves}

The patterns of announcement effects implied by the estimated parameters look quite different across the three groups of announcements. Using the parameter estimates from Table 5, Figure 2 plots for 
(a) Loading on short-rate factor

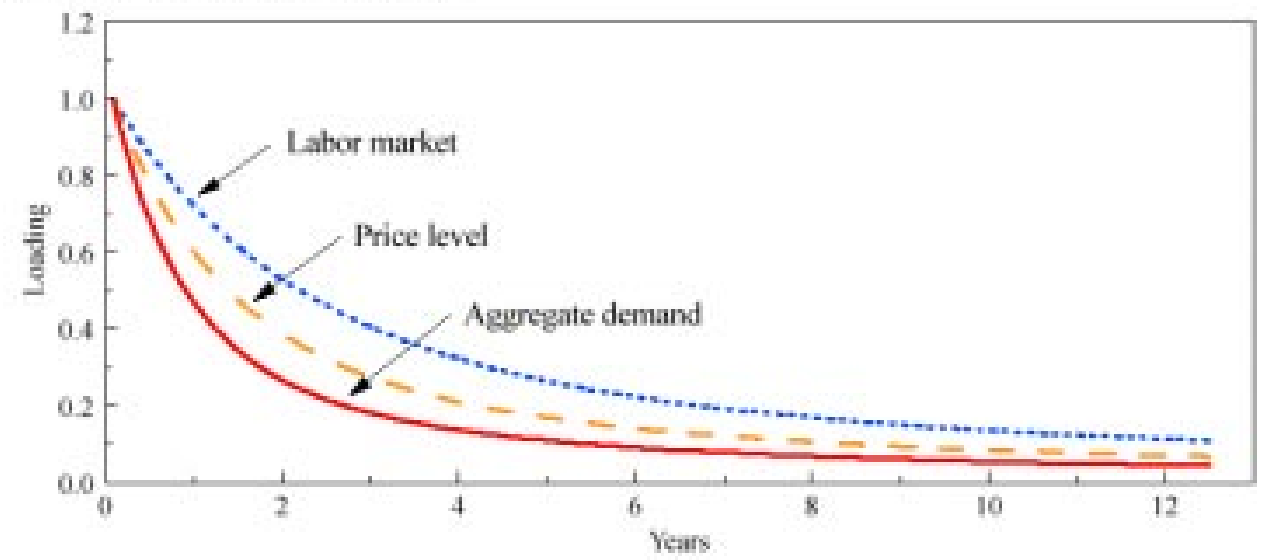

(b) Loading on stochastic mean factor

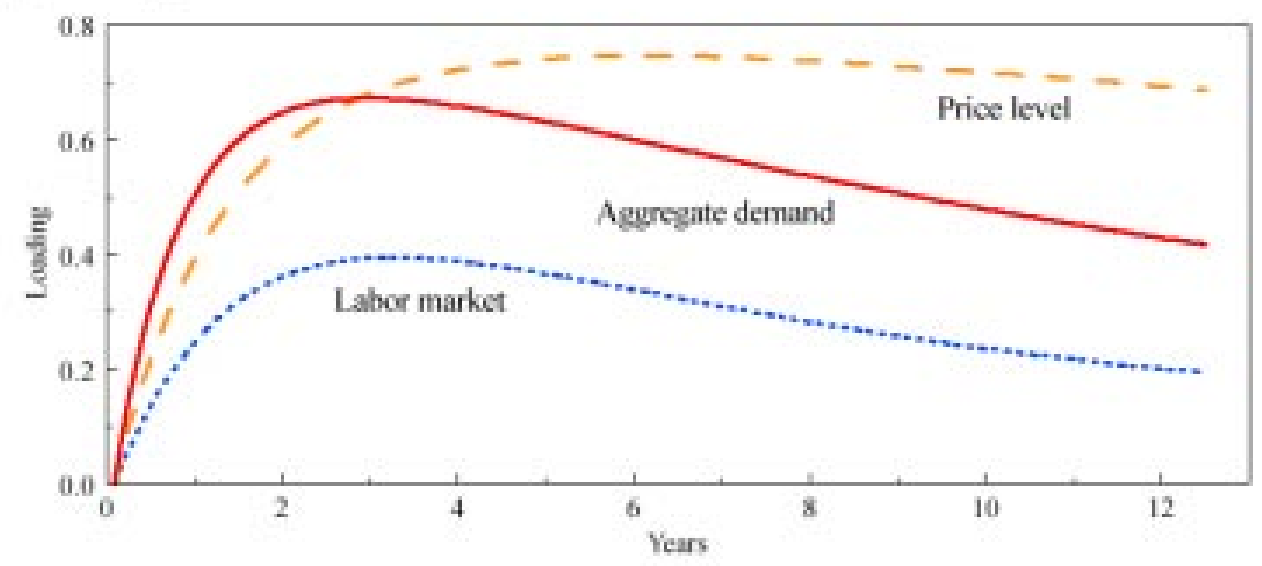

(c) Combined loading on short-rate and stochastic mean factors

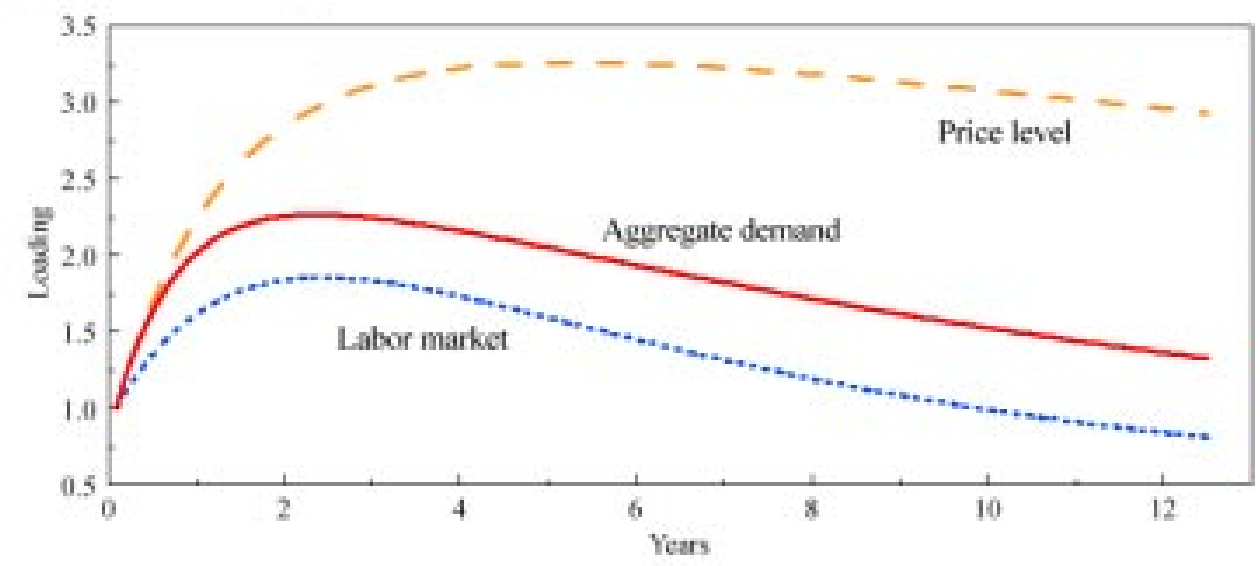

Fig. 2. Affine-yield model factor loadings. Curves are generated from GMM parameter estimates of a two-factor affine-yield model that is fit to announcement surprises and Treasury yield changes for each of three groups of announcements. The sample period is July 1, 1991 to September 29 , 1995. 
each group the loading on the short-rate factor, the loading on the stochastic mean factor and the combined loading on the short-rate and stochastic mean factors (in all cases setting the one-month loading equal across groups). Differences in the estimates of the short-rate persistence parameter result in a short-rate factor loading curve that is lowest for the aggregate demand announcements and highest for the labour market announcement, with the curve for price level announcements in between. Differences in the estimates of the stochastic mean persistence parameter result in stochastic mean factor loading curves that are clearly hump-shaped for the aggregate demand and labour market announcements, but that hardly fall at all with maturity for the price level announcements. Combining the short-rate and stochastic mean factors, with consideration of the higher relative shock size to the mean, again results in curves that are hump-shaped for the aggregate demand and labour market announcements, but that hardly fall with maturity for the price level announcements. The peak maturities of the combined loading curves, reported in Table 6, are a close 29 and 30 months for the aggregate demand announcements and labour market announcements respectively, but a much longer 65 months for the price level announcements.

Table 6

Half lives and peak maturities

\begin{tabular}{|c|c|c|c|}
\hline & $\begin{array}{c}\text { Labour market } \\
\text { announcement }\end{array}$ & $\begin{array}{c}\text { Price level } \\
\text { announcements }\end{array}$ & $\begin{array}{c}\text { Aggregate demand } \\
\text { announcements }\end{array}$ \\
\hline Short-rate half life (months) & 10.9 & 6.7 & 4.2 \\
\hline Stochastic mean half life (months) & 20.1 & 149.4 & 50.0 \\
\hline Peak maturity (months) & 30 & 65 & 29 \\
\hline \multicolumn{4}{|c|}{$\begin{array}{l}\text { Notes: The table reports the expected half lives for the shock to the short rate and the shock to the expected future targe } \\
\text { rate as well as the duration of the Treasury security whose yield is most affected by the shocks for each of three groups o } \\
\text { announcements. The estimates are derived from a two-factor affine-yield model that is fit to announcement surprises and } \\
\text { Treasury yield changes (the model is specified in equations (10) to (21)). The announcement groups are: labour marke } \\
\text { (nonfarm payrolls), price level (consumer price index and producer price index), and aggregate demand (durable goods } \\
\text { orders, housing starts, and retail sales). The sample period is } 1 \text { July } 1991 \text { to } 29 \text { September } 1995 \text {. }\end{array}$} \\
\hline
\end{tabular}

Figure 3 plots the constrained announcement impact curves generated from the Table 5 parameter estimates. These curves are the combined loading curves plotted in Figure 2 multiplied by the estimated scale parameters for the particular announcements. For comparison, Figure 3 also reports the least squares regression coefficients for the eight on-the-run securities. The estimated announcement impact curves seem to reasonably explain the patterns of announcement effects uncovered in Section 3. The curves do not fit perfectly, of course, because the effects are restricted to be consistent with an equilibrium model of expectations. In addition, the curves in Figure 3 are from the grouped estimates of Table 5, in which the market is presumed to respond similarly to different announcements of a given type. 
(a) Nonfarm payrolls

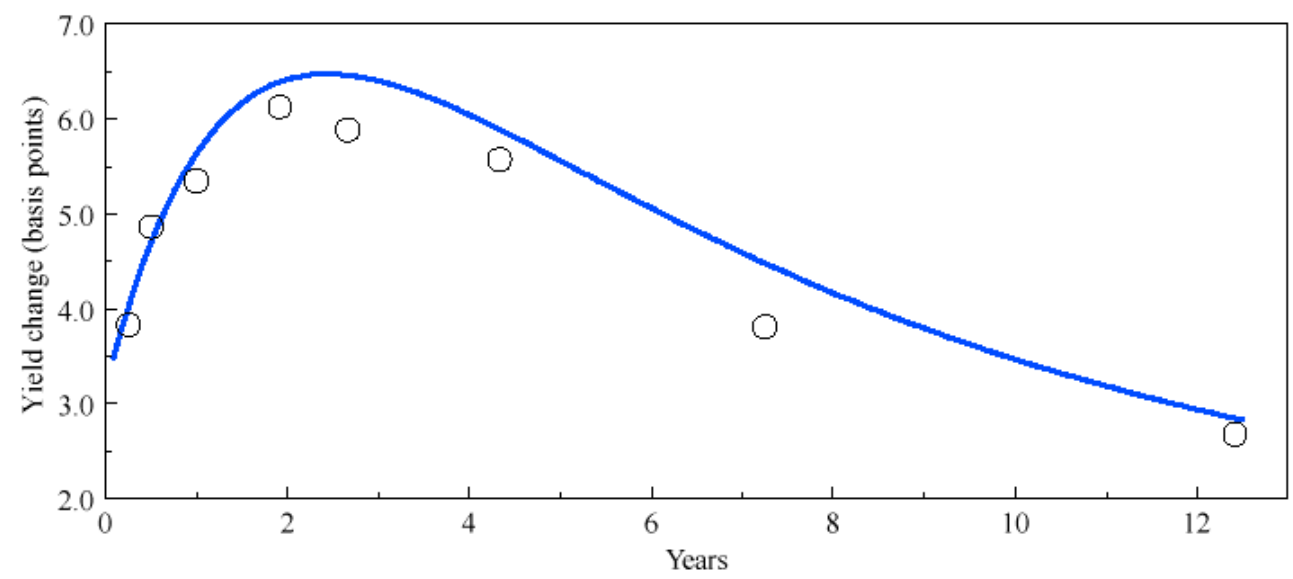

(b) Consumer price index

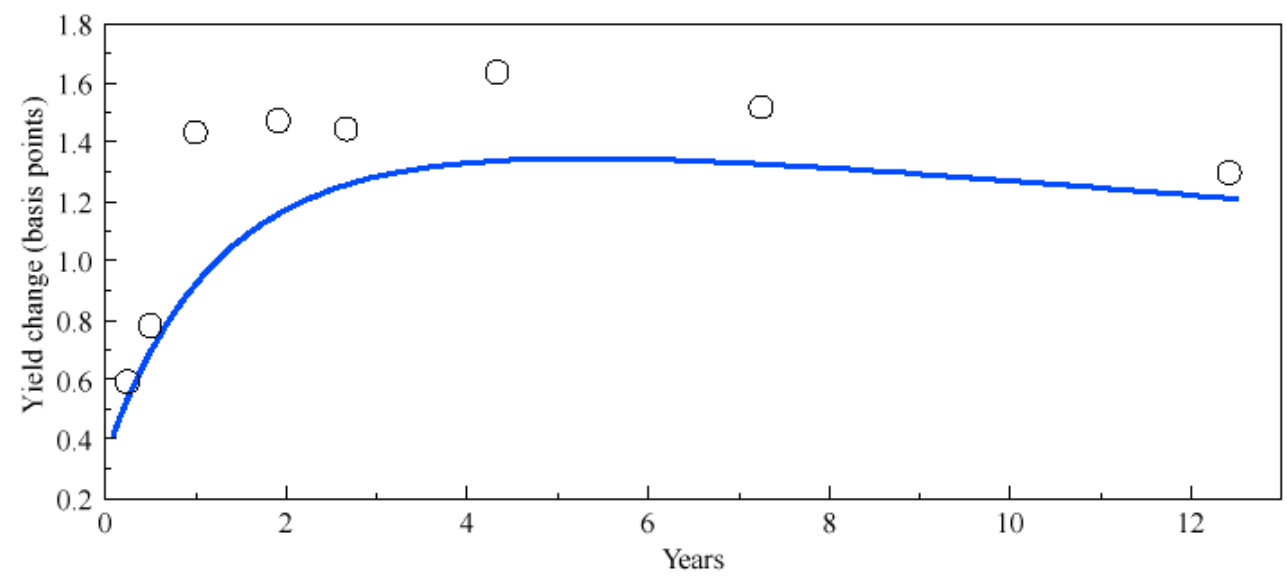

(c) Producer price index

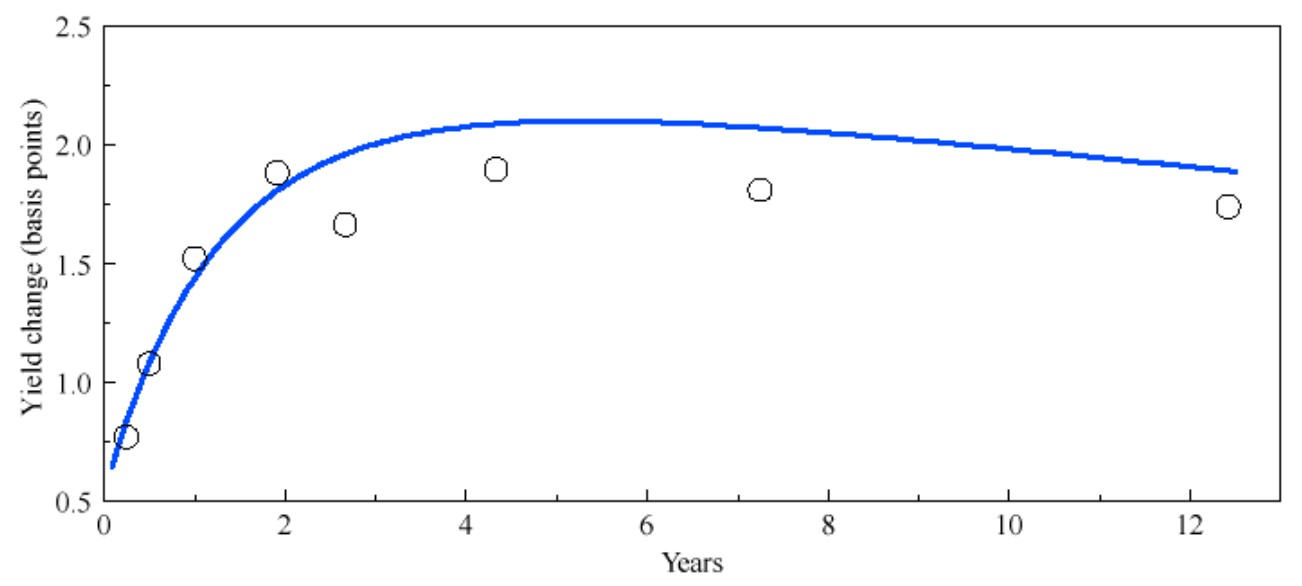

Fig. 3. Constrained impact of announcement surprises on Treasury yields. Curves are generated from GMM parameter estimates of a two-factor affine-yield model that is fit to announcement surprises and Treasury yield changes. Circles represent coefficients from least squares regressions of Treasury yield changes on announcement surprises. The sample period is July 1, 1991 to September 29, 1995. 
(d) Durable goods orders

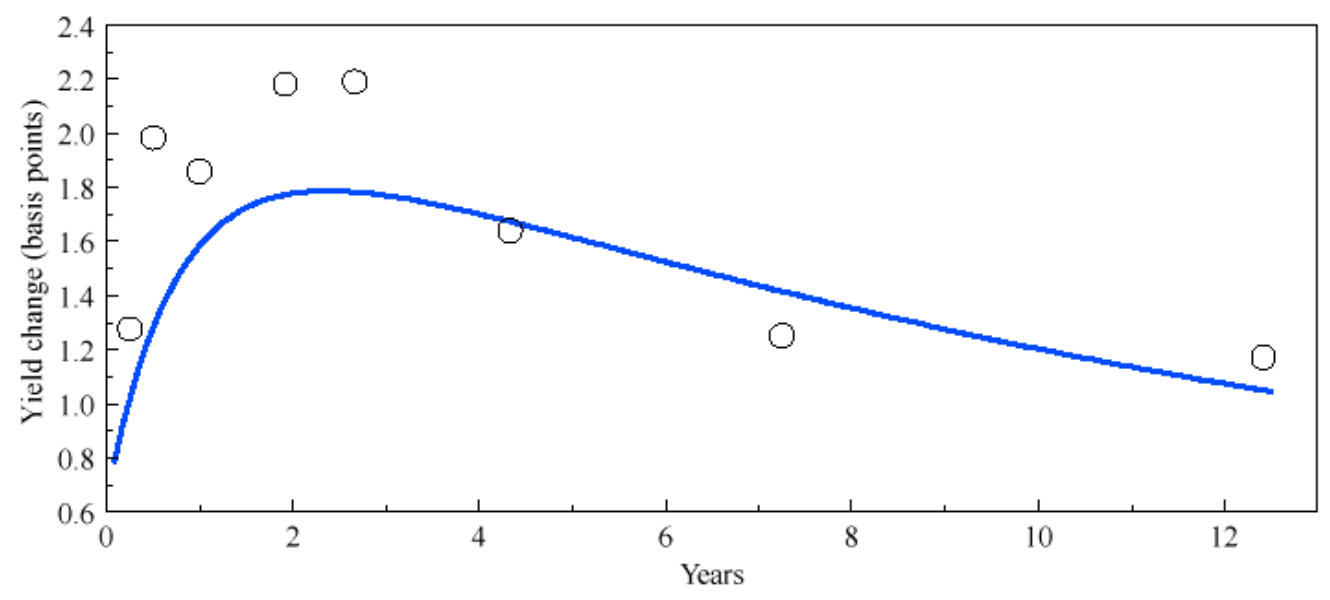

(e) Housing starts

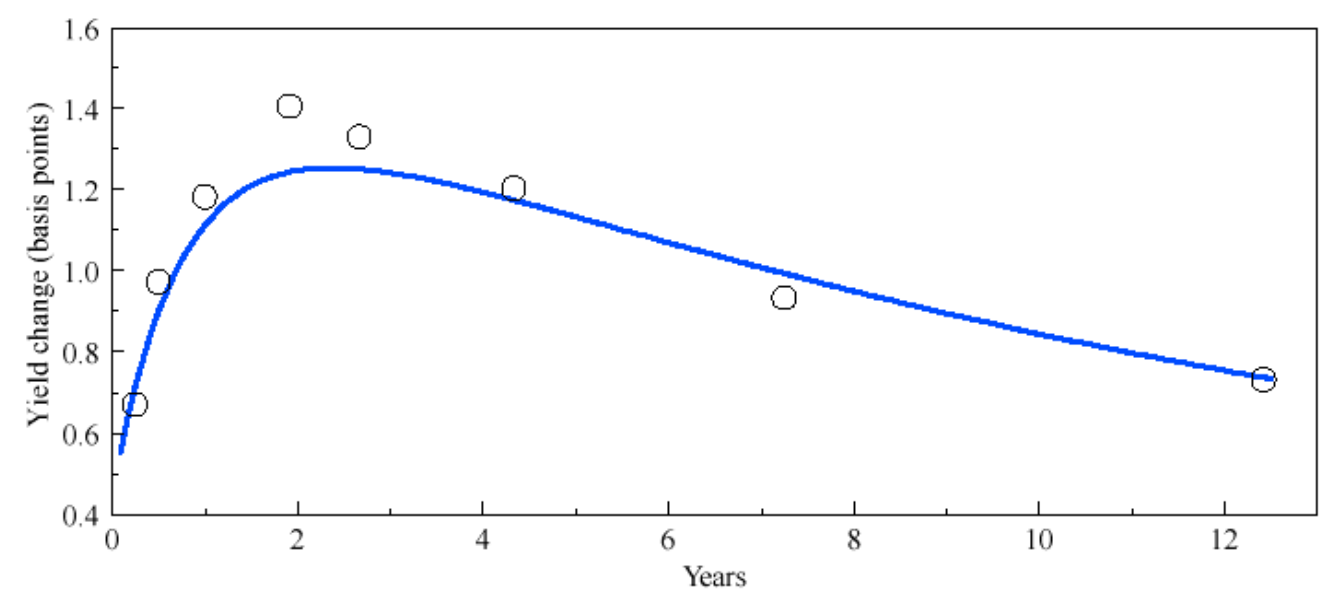

(f) Retail sales

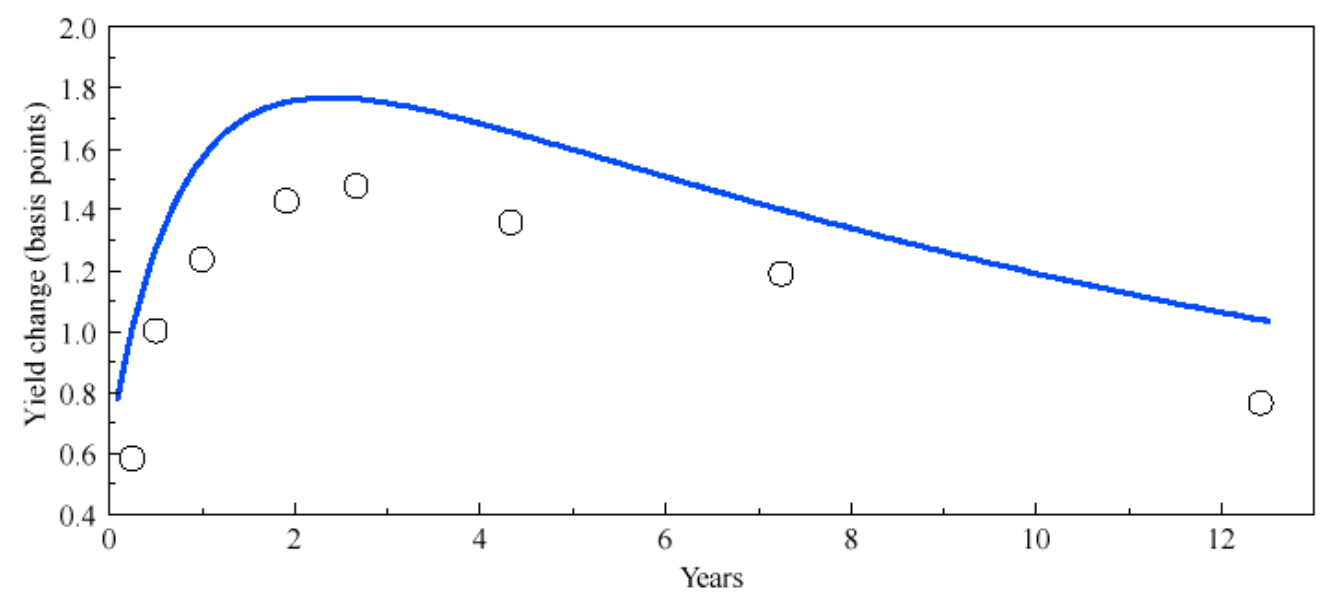

Fig. 3 (continued). 


\section{Conclusion}

In this paper, we document and interpret the high-frequency impact of macroeconomic announcements on the entire yield curve. We first estimate the effects of different announcements on the yield curve without the constraints of a term-structure model by regressing yield changes at announcement release times on corresponding announcement surprises. We then estimate the announcement effects so that they are consistent with factor loadings implied by an affine-yield model whose specification is suggested by the unconstrained estimates. We derive these constrained estimates by means of a GMM procedure in which we use the announcement surprises as instruments.

The unconstrained estimates reveal striking patterns in the yield curve's responses. The announcement effects are relatively weak for the short maturities and strong for the intermediate maturities of one to five years. When plotted by maturity, these effects form hump-shaped curves. At the same time, the particular shapes of these curves differ somewhat by announcement type. The price level announcements (CPI and PPI), in particular, exhibit a response for longer-term securities that is roughly as strong as that for intermediate-term securities, whereas other announcements exhibit significantly weaker responses at the long end of the yield curve.

The estimates constrained by the affine-yield model allow us to relate the shapes of the announcement curves to parameters that describe interest rate expectations processes. The specific model we fit is one in which a short-rate factor reverts to a stochastic mean factor and in which both factors are subject to announcement shocks. The resulting estimates imply that the announcements elicit much larger shocks to an expected future target rate than to the short rate, thereby forming hump-shaped impact curves. Furthermore, different types of announcements generate different expectations about the target rate, how rapidly it will be approached and how long it will be maintained. The price level announcements, in particular, elicit a much longer-lasting shock to the stochastic mean than the other announcements.

The finding that different groups of announcements lead to fundamentally different revisions in expectations points out the gains of linking empirical models of the term structure to specific information arrival and the usefulness of high-frequency data for such models. Until now, studies have typically estimated term-structure models with interest rate data without regard to the news that causes the rates to change. In this paper, we find that there is enough heterogeneity in arriving information to justify an explicit consideration of the different types of information when estimating term-structure models. While our analysis is limited to the information contained in ten scheduled macroeconomic announcements, future analysis of other scheduled as well as unscheduled announcements is likely to uncover further differences in the term structure's response to information arrival. 


\section{Appendix A}

\section{Parameter estimates for individually estimated models}

Panel A: Labour market and price level announcements

\begin{tabular}{|c|c|c|c|c|c|c|}
\hline \multirow{2}{*}{$\begin{array}{l}\text { Parameters } \\
\text { Short-rate persistence } \phi\end{array}$} & \multicolumn{2}{|c|}{ Nonfarm payrolls } & \multicolumn{2}{|c|}{$\begin{array}{c}\text { Consumer price } \\
\text { index }\end{array}$} & \multicolumn{2}{|c|}{ Producer price index } \\
\hline & 0.938 & $(0.264)$ & 0.812 & $(0.451)$ & 0.817 & $(0.465)$ \\
\hline Stochastic mean persistence $\theta$ & 0.966 & $(0.106)$ & 0.992 & $(0.017)$ & 0.997 & $(0.011)$ \\
\hline Relative shock size $\gamma$ & 3.626 & $(4.509)$ & 23.885 & $(487.52)$ & 12.470 & $(147.21)$ \\
\hline Scale parameter $\alpha$ & 3.487 & $(6.331)$ & 0.088 & $(1.798)$ & 0.170 & $(2.179)$ \\
\hline \multicolumn{7}{|l|}{ Risk premia $\rho_{n}$} \\
\hline 3-month bill & -0.046 & $(1.157)$ & 2.320 & $(58.467)$ & 5.517 & $(73.311)$ \\
\hline 6-month bill & 0.164 & $(1.241)$ & 2.383 & $(55.230)$ & 5.519 & $(75.532)$ \\
\hline 1-year bill & 0.186 & $(1.349)$ & 0.910 & $(36.593)$ & 7.605 & $(104.86)$ \\
\hline 2-year note & -0.062 & $(1.444)$ & -2.335 & $(59.179)$ & 7.001 & $(97.640)$ \\
\hline 3-year note & -0.139 & $(1.570)$ & -3.235 & $(73.499)$ & 4.671 & $(68.032)$ \\
\hline 5-year note & -0.044 & $(1.280)$ & 0.803 & $(40.056)$ & 5.361 & $(78.957)$ \\
\hline 10-year note & -0.083 & $(1.029)$ & 3.096 & $(70.322)$ & 3.282 & $(50.973)$ \\
\hline 30-year bond & -0.021 & $(0.752)$ & 2.367 & $(57.403)$ & 2.760 & $(42.250)$ \\
\hline J-statistic & 6.197 & & 8.073 & & 2.392 & \\
\hline Overidentifying restrictions & 4 & & 4 & & 4 & \\
\hline p-value & 0.185 & & 0.089 & & 0.664 & \\
\hline
\end{tabular}

Panel B: Aggregate demand announcements

\begin{tabular}{|c|c|c|c|c|c|c|}
\hline \multirow{2}{*}{$\begin{array}{l}\text { Parameters } \\
\text { Short-rate persistence } \phi\end{array}$} & \multicolumn{2}{|c|}{$\begin{array}{c}\text { Durable goods } \\
\text { orders }\end{array}$} & \multicolumn{2}{|c|}{ Housing starts } & \multicolumn{2}{|c|}{ Retail sales } \\
\hline & 0.500 & $(2.029)$ & 0.821 & $(1.070)$ & 0.697 & $(1.504)$ \\
\hline Stochastic mean persistence $\theta$ & 0.990 & $(0.008)$ & 0.984 & $(0.037)$ & 0.987 & $(0.035)$ \\
\hline Relative shock size $\gamma$ & 5.604 & $(67.119)$ & 4.512 & $(21.440)$ & 11.598 & $(159.16)$ \\
\hline Scale parameter $\alpha$ & 0.447 & $(5.417)$ & 0.411 & $(2.355)$ & 0.183 & $(2.564)$ \\
\hline \multicolumn{7}{|l|}{ Risk premia $\rho_{n}$} \\
\hline 3-month bill & -0.927 & $(11.308)$ & -0.155 & $(1.863)$ & 3.087 & $(41.745)$ \\
\hline 6-month bill & -0.650 & $(8.375)$ & 0.564 & $(4.325)$ & 3.596 & $(50.728)$ \\
\hline 1-year bill & 0.457 & (7.390) & 0.961 & $(6.175)$ & 4.796 & $(65.969)$ \\
\hline 2-year note & 0.623 & $(8.079)$ & 0.707 & $(5.626)$ & 5.592 & $(75.510)$ \\
\hline 3-year note & -0.417 & $(6.875)$ & 0.680 & $(5.199)$ & 5.652 & $(76.616)$ \\
\hline 5-year note & -0.190 & $(4.890)$ & 0.725 & $(5.398)$ & 6.128 & $(83.505)$ \\
\hline 10-year note & -0.207 & $(4.472)$ & 0.482 & $(4.445)$ & 5.632 & $(77.886)$ \\
\hline 30-year bond & -0.145 & (3.746) & 0.292 & $(3.875)$ & 4.060 & $(56.542)$ \\
\hline J-statistic & 21.364 & & 1.734 & & 0.852 & \\
\hline Overidentifying restrictions & 4 & & 4 & & 4 & \\
\hline p-value & 0.000 & & 0.785 & & 0.931 & \\
\hline
\end{tabular}




\section{Appendix B}

\section{Half lives and peak maturities for individually estimated models}

Panel A: Labour market and price level announcements

\begin{tabular}{lccc}
\hline & Nonfarm payrolls & $\begin{array}{c}\text { Consumer price } \\
\text { index }\end{array}$ & Producer price index \\
\hline Short-rate half life (months) & 10.9 & 3.3 & 3.4 \\
Stochastic mean half life (months) & 20.1 & 85.3 & 259.7 \\
Peak maturity (months) & 30 & 40 & 66 \\
\hline
\end{tabular}

Panel B: Aggregate demand announcements

\begin{tabular}{lccc}
\hline & $\begin{array}{c}\text { Durable goods } \\
\text { orders }\end{array}$ & Housing starts & Retail sales \\
\hline Short-rate half life (months) & 1.0 & 3.5 & 1.9 \\
Stochastic mean half life (months) & 65.7 & 42.6 & 51.6 \\
Peak maturity (months) & 20 & 27 & 24 \\
\hline
\end{tabular}

Notes: The table reports the expected half lives for the shock to the short rate and the shock to the expected future target rate as well as the duration of the Treasury security whose yield is most affected by the shocks for each of six announcements. The estimates are derived from a two-factor affine-yield model that is fit to announcement surprises and Treasury yield changes (the model is specified in equations (10) to (21)). The sample period is 1 July 1991 to 29 September 1995. 


\section{References}

Amin, Kaushik I and Andrew J Morton (1994): "Implied volatility functions in arbitrage-free term structure models". Journal of Financial Economics, 35, pp. 141-80.

Backus, David and Stanley E Zin (1994): "Reverse engineering the yield curve". Working paper, New York University, New York, NY.

Balduzzi, Pierluigi, Sanjiv Ranjan Das and Silverio Foresi (1998): "The central tendency: A second factor in bond yields". Review of Economics and Statistics, 80, pp. 62-72.

Balduzzi, Pierluigi, Edwin J Elton and T Clifton Green (1998): "Economic news and the yield curve: Evidence from the U.S. Treasury market”. Working paper, New York University, New York, NY.

Campbell, John Y, Andrew W Lo and A Craig MacKinlay (1997): "Econometrics of Financial Markets". Princeton University Press, Princeton, NJ.

Chen, Ren-Raw and Louis Scott (1993): "Maximum likelihood estimation for a multifactor equilibrium model of the term structure of interest rates". Journal of Fixed Income, 3, pp. 14-31.

Clarida, Richard, Jordi Gali and Mark Gertler (1999): "The science of monetary policy: A new Keynesian perspective". Journal of Economic Literature, forthcoming.

Cook, Timothy and Thomas Hahn (1987): "The reaction of interest rates to unanticipated Federal Reserve actions and statements: Implications for the money announcement controversy". Economic Inquiry, 25, pp. 511-34.

Cornell, Bradford (1983): "Money supply announcements and interest rates: Another view". Journal of Business, 56, pp. 1-23.

Cox, John, Jonathan Ingersoll and Stephen A Ross (1985): "A theory of the term structure of interest rates". Econometrica, 53, pp. 385-407.

Dai, Qiang and Kenneth J Singleton (1999): "Specification analysis of affine term structure models". Working paper, Stanford University, Stanford, CA.

Duffie, Darrell and Rui Kan (1996): “A yield factor model of interest rates". Mathematical Finance, 6, pp. 379-406.

Duffie, Darrell and Kenneth J Singleton (1997): "An econometric model of the term structure of interest-rate swap yields". Journal of Finance, 52, pp. 1287-321.

Ederington, Louis H and Jae Ha Lee (1993): "How markets process information: News releases and volatility". Journal of Finance, 48, pp. 1161-91.

Edison, Hali J (1996): "The reaction of exchange rates and interest rates to news releases". Board of Governors of the Federal Reserve System, International Finance Discussion Paper No. 570 (October).

Fleming, Michael J (1997): "The round-the-clock market for U.S. Treasury securities". Federal Reserve Bank of New York Economic Policy Review (July), pp. 9-32.

Fleming, Michael J and Eli M Remolona (1997): "What moves the bond market?" Federal Reserve Bank of New York Economic Policy Review (December), pp. 31-50.

Fleming, Michael J and Eli M Remolona (1998): "Price formation and liquidity in the U.S. Treasury market: The response to public information". Journal of Finance, forthcoming.

Gong, Frank and Eli M Remolona (1997a): "Two factors along the yield curve". Papers in Money, Macroeconomics and Finance: The Manchester School Supplement 1997, pp. 1-31.

Gong, Frank and Eli M Remolona (1997b): "A three-factor econometric model of the U.S. term structure". Federal Reserve Bank of New York Staff Reports No. 19 (January). 
Grossman, Jacob (1981): “The 'rationality' of money supply expectations and the short-run response of interest rates to monetary surprises". Journal of Money, Credit and Banking, 13, pp. 409-24.

Hansen, Lars Peter (1982): "Large sample properties of generalized method of moments estimators". Econometrica, 50, pp. 1029-54.

Hardouvelis, Gikas A (1988): "Economic news, exchange rates and interest rates". Journal of International Money and Finance, 7, pp. 23-35.

Heath, David, Robert Jarrow and Andrew Morton (1992): "Bond pricing and the term structure of interest rates: A new methodology for contingent claims valuation". Econometrica, 60, pp. 77-105.

Ho, Thomas S Y and Sang-Bin Lee (1986): "Term structure movements and pricing interest rate contingent claims". Journal of Finance, 41, pp. 1011-29.

Jeffrey, Andrew (1998): "An empirical examination of a path-dependent term structure model". Working paper, Yale School of Management, New Haven, CT.

Jegadeesh, Narasimhan and George G Pennacchi (1996): "The behavior of interest rates implied by the term structure of Eurodollar futures". Journal of Money, Credit and Banking, 28, pp. 426-46.

Jones, Charles M, Owen Lamont and Robin L Lumsdaine (1998): "Macroeconomic news and bond market volatility." Journal of Financial Economics, 47, pp. 315-37.

Longstaff, Francis A and Eduardo S Schwartz (1992): "Interest rate volatility and the term structure: A two-factor general equilibrium model”. Journal of Finance, 47, pp. 1259-82.

Pearson, Neil D and Tong-Sheng Sun (1994): "Exploiting the conditional density in estimating the term structure: An application to the Cox, Ingersoll and Ross model". Journal of Finance, 49, pp. 1279-304.

Roley, V Vance and Carl E Walsh (1985): "Monetary policy regimes, expected inflation and the response of interest rates to money announcements". Quarterly Journal of Economics, 100, Supplement, pp. 1011-39.

Rudebusch, Glenn D (1995): "Federal Reserve interest rate targeting, rational expectations and the term structure". Journal of Monetary Economics, 35, pp. 245-74.

Urich, Thomas and Paul Wachtel (1981): "Market response to the weekly money supply announcements in the 1970s". Journal of Finance, 36, pp. 1063-72.

Vasicek, Oldrich (1977): “An equilibrium characterization of the term structure”. Journal of Financial Economics, 5, pp. 177-88. 


\section{Recent BIS Working Papers}

No.

55

June 1998

56

June 1998

57

July 1998

58

November 1998

59

November 1998

60

November 1998

61

November 1998

62

March 1999

63

March 1999

64

March 1999

65

April 1999

66

April 1999

67

May 1999

68

May 1999

69

June 1999

70

June 1999
Title

Spread overreaction in international bond markets

Gregory D Sutton

Commercial banks in the securities business: a review

João A C Santos

Srichander

Ramaswamy

The importance of bank seniority for relationship

lending

Portfolio selection using fuzzy decision theory

Output gap uncertainty: does it matter for the Taylor rule?

Foreign direct investment and employment in the industrial countries

The pricing of bank lending and borrowing: evidence from the federal funds market

Microeconomic inventory adjustment and aggregate dynamics

Precarious credit equilibria: reflections on the Asian financial crisis

Higher profits and lower capital prices: is factor allocation optimal?

Evolving international financial markets: some implications for central banks

The cyclical sensitivity of seasonality in US employment

The evolution and determinants of emerging market credit spreads in the $1990 \mathrm{~s}$

Credit channels and consumption in Europe: empirical evidence

Interbank exposures: quantifying the risk of contagion
Stanley D Longhofer and João A C Santos

Srichander

Ramaswamy

Frank Smets

P S Andersen and $\mathrm{P}$ Hainaut

Craig H Furfine

Jonathan McCarthy and Egon Zakrajšek

Joseph Bisignano

P S Andersen, M Klau and $\mathrm{E}$ Yndgaard

William R White

Spencer Krane and William Wascher

Steven B Kamin and Karsten von Kleist

Gabe de Bondt

Craig H Furfine 
ISSN 1020-0959 